Estrategias de recuperación de territorios con presencia pandilleril y sus efectos en la convivencia de los habitantes de la residencial Los Chorros, cantón Las Angosturas, municipio de Colón, departamento de La Libertad, año $2015^{1}$

\author{
Autores \\ José Jaime Cabrera Soriano \\ Miguel Felipe Vega Palacios \\ Miguel Ángel Delgado Juárez
}

\title{
Introducción
}

El estudio tiene como objetivo identificar la estructura organizativa, el modus operandi, las principales acciones delictivas y las zonas de control territorial de la pandilla que opera en la residencial Los Chorros; además, proponer estrategias integrales que coadyuven a la erradicación de la delincuencia. Los hallazgos obtenidos en el estudio servirán para que los actores claves tengan conocimiento objetivo de su realidad y puedan valorar la incidencia (delictiva) y las potencialidades en el desarrollo de programas sociales y económicos, que permitan garantizar y proteger a las familias y jóvenes del fenómeno delincuencial y construir una área de convivencia y armonía social en la residencial Los Chorros.

\section{Antecedentes históricos}

Antes de los años setenta la palabra "mara" se utilizaba para identificar a un grupo de personas que compartían alguna actividad, a un grupo de amigos o allegados con intereses comunes, a quienes pertenecían a un sector social o incluso para dirigirse a la población en general. Se utilizaba para identificar a grupos de personas.

En el estado de California, Estados Unidos, inició la organización de los jóvenes salvadoreños en "maras de salvadoreños", primero como grupos de autodefensa, para protegerse de las pandillas rivales y posteriormente cada una fue tomando su propio cariz, incluso criminal.

1 Trabajo de graduación para optar al grado de Inspector Jefe de la Policía Nacional Civil de El Salvador, desarrollado en el IV curso de ascenso de la categoría de Inspector a Inspector Jefe, impartido por la Academia Nacional de Seguridad Pública en el año 2015. Título original del trabajo: "Las estrategias de recuperación por parte del Estado en los territorios con presencia delincuencial y sus efectos en el am. biente que viven los habitantes de la residencial Los Chorros, catón las Angosturas, municipio de Colón, departamento de La Libertad". El documento original ha sido editado por el CINC-ANSP para efectos de producir una versión publicable en la revista "Policía y Seguridad Pública". 
Allí van absorbiendo adherencias, costumbres, vicios de otras culturas, en especial de los delincuentes provenientes las mafias norteamericanas y de las bandas de mexicanos, puertorriqueños y de migrantes de África y Asia, entre otros. Se trasforman de un grupo que comparte su nacionalidad a un grupo que tiene que defenderse de muchas variables, de muchos y extremos peligros: necesidad de pertenecer a un grupo que los protegiera, especialmente, de las pandillas de mexicanos que dominaban el terreno, así como de la permanente deportación hacia su país de origen, lograron un entrecruce de culturas en tan corto tiempo, que ni psicólogos, ni sociólogos lo previeron.

De ahí en adelante, la vorágine implacable se apodera de El Salvador con los deportados por haber cometido delitos graves y se fueron ubicando en diferentes territorios que defienden a fuego y sangre.

Sobre el origen de las pandillas y su accionar en los inicios existen varios libros, artículos, blogs, noticias en periódicos virtuales y otras fuentes accesibles en la internet que pueden ser consultados por lectores que deseen poner en contexto histórico el llamado "fenómeno de las maras".

\section{Características de estudio}

\subsection{Contexto social del estudio}

El estudio se ejecutó en la residencial Los Chorros, situada en el cantón Las Angosturas, al poniente del municipio de Colón.

Este municipio en el año 2010 ocupaba los primeros lugares, como uno de los más violentos, posicionándose dentro de los primeros tres lugares del top 10 de los más violentos, lo cual provocó un involucramiento de diferentes actores de gobiernos y de organizaciones internacionales, específicamente el gobierno de los Estados Unidos de Norte América, la República de Japón, así como de diferentes ONG, todos coadyuvando en el incremento de personal a la subdelegación de la Policía Nacional Civil (PNC), de Lourdes Colón, para dar cumplimiento a las exigencias de seguridad que se demandaban, pero que posteriormente fue debilitada, debido al traslado de elementos policiales hacia otros lugares, posiblemente no tan vulnerables en la seguridad (PNC, 2014).

La subdelegación policial ubicada allí presenta algunas debilidades institucionales y retos de seguridad, entre los cuales se pueden mencionar: el debilitamiento institucional por el traslado del pie de fuerza policial; algunas zonas y calles con falta de iluminación pública, varias viviendas abandonadas o usurpadas; diferentes accesos, algunos escabrosos, en todos los sectores de la residencial Los Chorros, predios baldíos peligrosos, 
lugares sin luz, parques en estado de abandono con presencia de sujetos que consumen bebidas alcohólicas y drogas no autorizadas, transporte en taxis piratas que utilizan los delincuentes para movilizarse y delinquir $y$, finalmente, la existencia de grupos delincuenciales, entre otras bandas que operan en los diferentes sectores. Por otra parte, la mayoría de ventas de drogas se da en los distintos parques del municipio de Colón, principalmente en la residencial Los Chorros, cantón Las Angosturas. En este sector se ejecutan homicidios y extorsiones por parte de los grupos delincuenciales, quienes se desplazan en esa residencial para generar temor y amenazas a los habitantes (PNC, 2014).

\subsection{Justificación}

La residencial Los Chorros, cantón Las Angosturas de Lourdes Colón, ha sido uno de los sectores más violentos del municipio, con mayor presencia de grupos que generan hechos delictivos tales como: delitos relativos a la vida (como homicidios) y a la integridad personal, al goce de la libertad individual, a la libertad sexual y a la seguridad personal, así como, los delitos relativos al patrimonio (hurtos, robos, extorsiones, receptación y usurpaciones), y también delitos relativos a la seguridad colectiva, haciendo hincapié en el acoso constante a todos los habitantes, con énfasis en las presiones sobre la niñez y juventud estudiantil, para que ingresen a sus estructuras criminales.

Hay que destacar que:

durante el año 2013-2014, el municipio de Colón fue considerado uno de los 20 municipios más violentos, incidencia que ha tenido sus efectos por el accionar de los grupos criminales; además las acciones de estos se han visto incrementadas, al grado de generar temor e inseguridad en la población, al empoderarse de los espacios territoriales, generando alta migración de la población hacia otros lugares (ver anexo 2, Fotos de casas deshabitadas) (PNC, s/f).

Los esfuerzos generales preventivos y represivos implementados por las instituciones del Estado (ver anexo 3, Líneas estratégicas de prevención y represión de los planes gubernamentales en materia de seguridad), no han logrado erradicar las estructuras delictivas en la residencial Los Chorros, ni garantizar que los habitantes del lugar se desarrollen en un ambiente de seguridad y tranquilidad, y la situación se agrava ante la complejidad de esas organizaciones provocando efectos cada vez más críticos. 


\subsection{Delimitación de la investigación}

El estudio tiene como delimitación espacial la residencial Los Chorros, cantón Las Angosturas, municipio de Colón, del departamento de La Libertad de El Salvador.

Sus límites (del municipio de Colón) se encuentran definidos: al norte por el municipio de San Juan Opico, al sur por los municipios de Jayaque y Talnique, al este por el municipio de Santa Tecla y al oeste por los municipios de Ciudad Arce, Sacacoyo y Colón. Posee una extensión territorial de $76.912 \mathrm{~km}$, de los cuales 4195, km corresponden al área urbana y 72.71 al área rural. En el municipio de Colón, se afincan los siguientes cantones: Las Angosturas, Las Brisas, Las Moras, El Capulín, Cuyagualo, Lourdes, El Cobanal, Hacienda Nueva, Botoncillal, El Limón, El Manguito y Entre Ríos (ver anexo 4, Cantones del municipio de Colón). (PNC, s/f).

El estudio se desarrolló en el período del 01 de enero a diciembre de 2014, tomando en cuenta que los grupos delincuenciales de maras y pandillas tuvieron una recomposición y movilización a nivel territorial, fortaleciendo la beligerancia delictiva, durante el proceso conocido como tregua entre pandillas.

Los siguientes actores que inciden en la residencial constituyen sujetos relevantes para el estudio:

a. El Estado salvadoreño y sus instituciones de seguridad, como ente principal en las políticas públicas en la materia.

b. Los grupos delincuenciales, como la Mara Salvatrucha (nombre generalmente abreviado como MS, Mara, y MS-13), organización nacional e internacional de pandilleros.

c. Actores locales como alcaldía, ONG, empresa privada, la Fiscalía General de la República en tanto sujetos articuladores en el proceso de prevención-represión, en función de integrarse a las acciones de recuperación de territorios y desarticulación de los grupos delincuenciales.

d. También son actores locales importantes todas las personas que habitan, frecuentan o visitan la residencial. 


\subsection{Alcances}

El estudio desarrollado ha permitido hacer un análisis de los grupos delincuenciales que tienen incidencia en la residencial permitiendo el conocimiento de su accionar territorial así como su modus operandi. Pero también ha permitido palpar el desasosiego en el que viven los habitantes y demás personas que visitan o frecuentan la residencial, aunque no sean residentes. También se analizó la configuración de escenarios para la intervención del problema y desarticulación de esos grupos, a través de la ejecución de estrategias integrales y operativas de recuperación de territorios.

En ese ámbito, se busca desarrollar mecanismos de confianza entre la Policía Nacional Civil y la población de la residencial Los Chorros, para fortalecer las políticas de seguridad que se planifican en el Consejo de Seguridad y Convivencia Ciudadana y el Ministerio de Justicia y Seguridad Pública (MJSP).

\subsection{Limitaciones}

El incremento de los enfrentamientos entre grupos delincuenciales con autoridades policiales y miembros de la Fuerza Armada generó un obstáculo para el levantamiento de información, por los riesgos y amenazas que estos representan. Poca colaboración de los actores claves a la hora del levantamiento de información, por temor a los grupos delincuenciales. Difícil acceso en los territorios controlados por los grupos delincuenciales en la residencial Los Chorros (ver anexo 5, Ubicación geográfica de la residencial Los Chorros).

\section{Objetivos}

\subsection{Objetivo general}

Proponer estrategias integrales que coadyuven a la erradicación de los grupos delincuenciales que operan en la residencial Los Chorros, cantón Las Angosturas, municipio de Colón del departamento de La Libertad.

\subsection{Objetivos específicos}

Identificar la estructura organizativa de los grupos delincuenciales que operan en la residencial Los Chorros, cantón Las Angosturas, municipio de Colón, departamento de La Libertad.

Conocer los límites geográficos de actuación de los grupos delincuenciales de la zona en estudio. 
Establecer el modus operandi y el apoyo brindado por la estructura y sus colaboradores.

\section{Marco referencial}

\subsection{Marco histórico}

El municipio de Colón constituye un entorno complejo para gestionar la seguridad, ya que se observan elementos negativos para el futuro de la población, afectada por una multiplicidad de factores, tales como: escasas zonas recreativas de sano esparcimiento (como zonas verdes y canchas de fútbol), ausencia de fuentes de empleos dignos y directos, desintegración familiar, accesos peatonales inseguros, predios baldíos, casas abandonadas, deficiente servicio de alumbrado público.

Ante tal situación, la subdelegación de Lourdes Colón implementó el nuevo modelo de filosofía de policía comunitaria, para tener un acercamiento con las comunidades, especialmente con la infancia y juventud, para generar resistencia ante la amenaza de los grupos delincuenciales (PNC, 2010a).

La subdelegación ha desarrollado esfuerzos propios para implementar la filosofía de policía comunitaria, a fin de ofrecer y desarrollar programas preventivos a centros escolares y organizar los actores claves de la comunidad y la cooperación internacional.

En el transcurrir del tiempo, los grupos delincuenciales se han visto fortalecidos en sus capacidades delictivas y nivel de organización, al grado de poseer armas de fuego cada vez más poderosas, las cuales las movilizan de diferentes maneras para evitar ser detectados por las autoridades policiales (PNC, 2010b).

Ante los niveles de violencia y presencia de los grupos delincuenciales, la subdelegación policial de Lourdes Colón, desarrolla diferentes acciones:

- Plan escuelas seguras,

- Asambleas de padres,

- Presentación de los patrulleros a los actores locales,

- Visitas casa por casa,

- Borrado de grafitis,

- Nombramiento de policías responsables de los subsectores, 


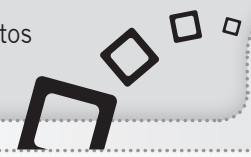

- Incremento de patrullas mixtas de miembros de la Policía Nacional Civil y soldados del Ejército Nacional. Estas patrullas son Ilamadas "Grupo Conjunto de Apoyo a la Comunidad" (GCAC).

Además se inauguró una base móvil con 15 policías, y un cabo al mando, realizando patrullajes continuos como dispone la filosofía de policía comunitaria; se instaló una oficina de policía comunitaria, con múltiples funciones y con 17 patrullas asignadas a los sectores, con enfoque comunitario, cada una con dos agentes. Con esto, según se informó, se logró una reducción notoria de la incidencia delincuencial.

En ese entorno, en lo referido a la difícil situación del fenómeno delincuencial, existen algunos factores, tanto internos como externos, que han contribuido al mantenimiento de algunos delitos que no se han erradicado así como a la generación de otros tipos de delitos.

A continuación se detallan los siguientes problemas delincuenciales y factores de riesgo:

- Constantes aplicaciones de medidas sustitutivas a la detención provisional, a delincuentes, inclusive reincidentes.

- Zona de vivienda propicia con costo accesible para los grupos delincuenciales y sus familiares.

- Zonas marginales con deficientes programas de desarrollo comunitario, contribuyendo a la generación de un ambiente delincuencial que es asimilado por menores en crecimiento.

- Inexistencia de directiva en las sendas de la residencial, por temor y amenazas de los delincuentes.

- La deserción escolar: según datos proporcionados por el MINED, durante el año 2014, se presentó una matrícula en el centro educativo público de 475 estudiantes; entre ellos se produjo un alto porcentaje de deserción escolar por el acoso delincuencial.

- No existe capacidad de atención a jóvenes de tercer ciclo y bachillerato en los centros escolares. Entre los centros educativos están un centro público, dos privados y tres urbano-rurales. En la residencial Los Chorros, se encuentran los centros escolares residencial Los Chorros, Colegio Doctora Coto y Colegio Mercedes Durán.

- La ejecución de programas de prevención ha sido una de las medidas con las que se ha proyectado minimizar los riesgos sociales y de inseguridad. Sin embargo, su efectividad ha sido parcial, ya que el fenómeno de los 
grupos delincuenciales continúa presente con la capacidad de generar mayores amenazas e inestabilidad a los habitantes; en ese sentido, se presentan algunos programas desarrollados en la comunidad de la residencial Los Chorros. Entre otros programas desarrollados en los centros escolares están el Plan de Protección Escolar, dentro del cual se desarrollan diferentes programas como GREAT (por sus siglas en inglés significa Educación y Entrenamiento en Resistencia a las Pandillas), de este se graduaron 210 estudiantes en el año 2014. También, se imparte el programa de prevención de delitos y del uso y abuso de drogas prohibidas.

- Para colaborar con los esfuerzos de la subdelegación policial de Lourdes Colón, se constituyeron socios estratégicos, con incidencia en la localidad, como el comité intersectorial del municipio de Colón, organizado en mesas de trabajo:

- Mesa de seguridad ciudadana;

- Mesa de salud y medio ambiente;

- Mesa de juventud, cultura, recreación y deportes;

- Mesa de personas con discapacidad y

- Mesa de desarrollo local.

Estas mesas están integradas por las entidades siguientes:

- Ministerio de Educación (MINED).

- Ministerio de Salud Pública y Asistencia Social (MINSAL).

- Instituto Salvadoreño del Seguro Social (ISSS).

- Plan Nacional (PLAN).

- Corte Suprema de Justicia (CSJ).

- Ministerio de Justicia y Seguridad Pública (MJSP).

- Instituto de Derechos Humanos de la UCA (IDHUCA).

- Instituto Nacional de la Juventud (INJUVE).

- Asociación Scout de El Salvador (SCOUT).

- Alcaldía municipal del municipio de Colón. 
En ese marco de acción es importante conocer los espacios geográficos que se ubican en residencial Los Chorros, ubicado en el km 25 sobre la carretera panamericana en el tramo que une a San Salvador con el departamento de Santa Ana. Aunado a esto, Colón limita al norte con el municipio de San Juan Opico, otra localidad de gran accionar delincuencial, lo cual vuelve al sector un corredor para el tránsito y afincamiento de la delincuencia que azota la zona.

En el año de 1997, la residencial Los Chorros inicia como la parcelación Agramonte; un año más tarde se inicia el proyecto para la construcción de la urbanización Agramonte; para el año 2004 se construyó la primera etapa y se concluyeron en el año de 2007 las siguientes dos. Queda así dividida la residencial Los Chorros en tres etapas. En esta última es donde se concentra la mayoría de miembros de la MS que delinquen.

El número de viviendas afincadas en cada una se detalla a continuación:

- En la primera etapa, 971 viviendas.

- En la segunda etapa, 509 viviendas.

- En la tercera etapa, 139 viviendas.

En total son 1619 viviendas, de las cuales se contabilizan 140 deshabitadas.

Una de las formas para hacer sentir que el espacio territorial es controlado por una mara es escribir mensajes en las paredes de las casas, como una señal de que es parte del espacio que controlan, como se puede observar en las fotografías de casas pintadas con grafitis de las maras de la MS 13 (ver anexo 6, Casas pintadas con grafitis).

La realidad social del fenómeno de los grupos delincuenciales no se reduce ni se neutraliza, sino que las maras y pandillas tienden a buscar un nivel de beligerancia mayor, al grado de tener la capacidad de enfrentarse a la autoridad policial. Se registran casos donde han utilizado armas de grueso calibre para sus hechos delictivos, en los homicidios han usado armas de fuego como pistolas, escopetas e incluso fusiles de asalto AK-47 y M-16, y hasta han recibido entrenamiento militar, según relatan medios de prensa.

La evolución de las pandillas denota el mejoramiento de sus formas de actuar día a día, en especial en su logística y la "efectividad" para delinquir. Cuando iniciaron empleaban armas rudimentarias y artesanales; en la actualidad poseen armas automáticas y de guerra.

En los ataques, generalmente se aseguran de no dejar a la víctima con vida, disparando así varias veces al cuerpo y cabeza con armas de fuego. En el 
caso de armas blancas, tienden a herir de muerte, incluso desmembrando a la persona atacada; rara vez los pandilleros llegan a recurrir a combate cuerpo a cuerpo. Además de usar armas para hechos delictivos de violencia las usan de contrabando para venderlas o distribuirlas entre sus mismos miembros (PNC, 2012).

La MS 13 se caracteriza por tener una alta capacidad y creatividad organizativa, expansión nacional e internacional, alta movilidad, vehículos para el tráfico de armas, drogas y personas, objetivos precisos a corto y mediano plazo, y, en especial, gran capacidad para adaptarse y superar el endurecimiento y la ejecución de medidas de seguridad.

\subsection{Consideraciones teóricas}

Como sujeto de estudio de la problemática delincuencial, se hizo necesario investigar la incidencia de los grupos delincuenciales que, en los últimos años, ha azotado la residencial Los Chorros, y los diferentes factores de riesgo, sociales, económicos y situacionales, que han generado los grupos criminales. Estos mantienen un nivel de intimidación y terror con amenazas a los habitantes de la comunidad, obligándoles a desalojar sus viviendas, manteniendo presencia territorial, lo que ha llevado al incremento de la violencia. En ese sentido, las categorías analítico-teóricas del fenómeno en estudio estarán enfocadas a analizar el papel del Estado, como ente generador de políticas preventivas y represivas de seguridad desde el Ministerio de Justicia y Seguridad Pública (MJSP), el cual direcciona líneas de acción estratégicas y operativas a la Policía Nacional Civil (PNC).

La armonía y tranquilidad de los ciudadanos de la residencial Los Chorros se encuentra en riesgo debido a los grupos delincuenciales, ya que son un fenómeno que se ha apoderado de la paz del país, generando mayor violencia; cada vez crecen organizativamente por sus métodos de reclutamiento. A diario los ciudadanos son objetos de asaltos en las calles, paradas de buses, parques, autobuses del transporte colectivo, tiendas, distribuidores de mercadería, además de esos delitos se cometen extorsiones, tráfico de drogas, violaciones y asesinatos con características de barbarie.

Algunos delincuentes justifican que ellos defienden su territorio de otros grupos por eso es que se enfrentan contra la mara contraria a la de ellos, y que los tatuajes que se hacen es para reflejar alguna historia triste que han tenido o para que las personas les guarden temor o respeto. Los tatuajes, las señales de manos, la manera de vestir y el peinado hacen que cada marero distinga a qué mara o pandilla pertenece, si es amigo o enemigo. Los mareros son personas muy peligrosas e irracionales que han perdido el verdadero concepto de conservación por la vida. Las maras son organizaciones estructuradas, cada grupo es dirigido por un jefe al que se 
debe obediencia como a un superior; los jefes de las maras o pandillas, por lo general, no realizan delitos, sino que dan órdenes a sus miembros y supervisan que el código de lealtad y fidelidad a la pandilla se cumpla.

En un estudio que realiza Dina Beatriz Escobar Rivera, señala:

La mayoría de mareros son jóvenes entre 16 a 25 años que dejan sus estudios para encargarse de extorsionar a empresarios del transporte colectivo, pequeños negocios, familias, y en el mercado informal, para ganar dinero fácil y no trabajar, para lo cual, ejercen amenazas a muerte a motoristas del transporte colectivo, que al no pagar la renta los propietarios de las empresas, las maras y pandillas terminan asesinando a los motoristas y cobradores. $Y$ en algunos casos a los propietarios del transporte.

Las autoridades de seguridad pública no alcanzan a cubrir las zonas más peligrosas ya que a diario hay más mareros, por el constante proceso de reclutamiento de nuevos miembros y su forma clandestina de operar como células.

Su bien estructurada organización, portadora de armas legales e ilegales, incorpora a sus filas a un aproximado de 32,000 jóvenes y niños, que han constituido un nuevo ejército que es usado por el crimen organizado para sus fines delictivos (Escobar Rivera, 2009).

Entre los múltiples factores que caracterizan las causales comunes en la proliferación de maras y pandillas se destacan:

el pertenecer a hogares desintegrados y disfuncionales, caracterizados por la violencia intrafamiliar, extrema pobreza, marginalidad, interrupción de los estudios a nivel primario y secundario, abandono de oficios, posibilidades de acceso al consumo y distribución de drogas y a la vida delictiva, con la consecuente obtención de dinero por medios fáciles e inicio precoz en la vida sexual.

Se destaca la transculturización, imitación y sentido de pertenencia al grupo para obtener y afirmar lo que no tuvieron en el seno familiar, comunidad y sociedad: importancia, identidad y ser "alguien" aunque sea por medios ilegítimos.

Además del desencanto y el escapismo, su mundo florece en plena expansión del narcotráfico, lo que hace que la proliferación del fenómeno trascienda inquietudes meramente juveniles para manifestarse en actividades delictivas para sobrevivir como grupo (Escobar Rivera, 2009). 
Las maras y pandillas, el crimen organizado y las drogas están bastante interrelacionados, tomando en cuenta que:

casi el $85 \%$ de mareros son consumidores de drogas y se dedican a la venta local, y de la distribución de la misma en barrios, escuelas y colegios. La población que integran las maras y pandillas en su mayoría es masculina y las muchachas (mujeres) representan el $23 \%$ de sus miembros. Sobre ellas se han comentado que sufren en los ritos de iniciación violaciones de parte de sus compañeros o son víctimas de abuso sexual por parte de miembros de las pandillas contrarias. Al consultárseles, sobre su rol más preponderante, dentro de las mismas, ellas se auto identifican más como compañeras que como mareras activas, de hecho, la gran mayoría han tenido hijos con pandilleros y han estado sujetas a la protección y cuidado del grupo (Escobar Rivera, 2009).

La situación de la violencia en el país, para ciertos sectores sociales, se ha convertido en un negocio que genera grandes rentas y ganancias; el crimen no paga impuestos; quienes tienen doble tributación son los ciudadanos, por un lado pagan al Gobierno sus impuestos y por el otro "tributan" a las maras (la mal Ilamada renta), para tener sus vidas a salvo ya que día a día salen a trabajar para sobrevivir junto a su familia.

Los pequeños empresarios tienen que gastar o presupuestar una cifra extra de dinero cuando son extorsionados por los mismos mareros, que les prometen no meterse con su negocio a cambio de una cantidad de dinero, las personas que trabajan en lugares que frecuentan los mareros o viven donde hay pandillas, tienen que darles cada vez que los encuentran de una a dos "coras" (veinticinco centavos de dólar), con una sonrisa, aunque no les guste, para mantenerlos contentos.

El actual entorno nacional de los grupos delincuenciales tiene su incidencia en zonas geográficas más vulnerables, siendo una de ellas la ya mencionada residencial objeto del estudio. Hay zozobra entre los habitantes, quienes temen hablar de los niveles de peligrosidad en la zona. Las pandillas les intimidan al grado de amenazar a comunidades enteras con el fin de ser reconocidos a la fuerza como buenos ciudadanos o ejemplares, a pesar de que son ellos los responsables de un alto porcentaje de los homicidios en todo el país.

Al organizarse en grupo, el joven toma una característica de valentía, de hombre fuerte que puede generar terror, eso le da un nivel de liderazgo; en cambio, como persona individual pierde esos valores, actúa diferente con algún temor de lo que hace, y se ve a sí mismo vulnerable. 
Tal es el caso en Lourdes, Colón, donde un pandillero es considerado a la fuerza como un "héroe" o "mártir" luego de morir al enfrentarse a agentes de la Policía.

Los pandilleros amigos tienen amenazada a toda la comunidad para que le rindan homenaje, ya que consideran que ofrendó su vida como un "buen soldado" de la MS (Elsalvador.com, 2011).

En el estudio requiere importancia analizar:

un caso en que la pandilla pretende recordar a Pablo Antonio Mojica, (a) "Chagui", quien murió junto a Samuel del Tránsito Zavala Herrera, otro marero, aparentemente luego de enfrentarse a tiros con una patrulla de la Policía.

El hecho tuvo su desenlace fatal en la residencial Los Chorros el 30 de octubre pasado.

Un mes después de la muerte, la MS se dedicó a repartir placas "conmemorativas" en la residencial para "conmemorar" a los dos pandilleros, pero sobre todo del "Chagui"; según el exjefe de la Delegación de Lourdes, Miguel Vallecillos.

El mensaje que se lee en el volante expresa: "El Hombo y el Chagui", soldados fieles y leales a la mara Salvatrucha, que peleó la buena batalla. Una buena vida llegó a su fin. Él murió siendo amigo de todos. En nuestros corazones siempre lo recordaremos. Su memoria a quienes siempre amamos; siempre lo vamos a recordar (Elsalvador.com, 2011).

En este hecho pone en evidencia el nivel de incidencia que ejercen en la población, por lo que:

el escrito ha sido cuestionado por el subcomisionado Miguel Ángel Guerrero Vallecillos, exjefe de la Delegación Policial de Lourdes Colón, porque intenta confundir la escala de valores de la sociedad al pretender idealizar o ver como buena la supuesta actividad delictiva de los pandilleros en el país.

El oficial recuerda que la MS es un grupo delincuencial que ha llegado al nivel mental que para ellos, el Chagui y el Hombo son hasta héroes o personas por imitar en sus acciones, con lo que buscan ganar adeptos en niños y jóvenes en zonas de alto riesgo.

En ningún momento la pandilla "los hace ver como homicidas o extorsionistas", actividades a las que se dedicaron durante su vida; para el subcomisionado Vallecillos, agrega que esta actitud denota "organización ideológica o mental de las maras". 
Vallecillos sostiene que el Chagui fue procesado por homicidio, pero salió libre porque supuestamente mandó a matar al testigo que había en su contra (Elsalvador.com, 2011).

La dinámica del problema de la delincuencia sigue su curso, en la residencial Los Chorros el panorama:

es desolador, pese a que en una de las zonas está instalada una unidad móvil de la PNC (...).

Se constató que en la unidad hay dos agentes, quienes solo tramitan denuncias de los ciudadanos, pero de ahí no salen ni a patrullar en la colonia.

A pocos pasos de la caseta policial hay un mural donde se observa una leyenda "Ver, oír y callar si tu vida quieres gozar".

En ese lugar fue abordada una vecina, a quien se le preguntó por la situación delincuencial en la colonia.

La mujer fue tajante en su respuesta: "Por lo mismo, aquí no se puede decir nada", en alusión a la advertencia escrita por la MS en la entrada de un pasaje (Elsavador.com, 2011).

Uno de los modus operandi de los grupos delincuenciales es que utilizan a los niños y adolescentes como "postas" (vigilancia), en la zona, que tienen una misión: alertar a los mareros de la presencia de un extraño o de algún contingente policial o militar.

Durante el 2011:

en los seis municipios a cargo de la delegación de Lourdes, Colón, se han registrado más de 120 homicidios, según el oficial Vallecillos.

Solo en Colón han sido ultimadas unas 70 personas, según su apreciación, el 90 \% de los crímenes de ese sectores atribuido a las maras y pandillas. Los homicidios en la zona norte de La Libertad tienen como móviles el tráfico de droga y la rivalidad entre las maras y pandillas (Elsalvador.com, 2011).

\subsection{Marco jurídico}

El estudio conlleva el análisis de la interrelación jurídica de diferentes instituciones del Estado, que tienen la facultad y potestad para aplicar medidas coercitivas, ante grupos delincuenciales que generan niveles de inseguridad en la ciudadanía, y que rompen la armonía y tranquilidad de los ciudadanos. 
El estudio se fundamenta en el siguiente marco jurídico:

- La Constitución de la República (1983), en el artículo 168, sobre las atribuciones y obligaciones del presidente de la República, en el numeral $17^{\circ}$, señala que son:

Organizar, conducir y mantener la Policía Nacional Civil para el resguardo de la paz, la tranquilidad, el orden y la seguridad pública, tanto en el ámbito urbano como en el rural, con estricto apego al respeto a los Derechos Humanos y bajo la dirección de autoridades civiles (Constitución de la República, 1983).

- Ley Orgánica de la Policía Nacional Civil, artículo 4, donde se establecen las funciones de la corporación policial, que tiene la potestad para mantener la paz interna, la tranquilidad, el orden y la seguridad pública, combatir toda clase de delitos con estricto apego a la Ley.

- Ley Penal Juvenil. En su artículo 2, establece que "se aplicará a las personas mayores de doce años de edad y menores de dieciocho". Los grupos delincuenciales, se han aprovechado de esta Ley, ya que han visto las ventajas de utilizar a los menores de edad, para la comisión de delitos.

\section{- Ley contra el Crimen Organizado y Delitos de Realización Compleja.}

El artículo 1 plantea que:

la ley tiene como objeto regular y establecer la competencia de los tribunales especializados y los procedimientos para el juzgamiento de los delitos cometidos bajo la modalidad de crimen organizado o de realización compleja. Se considera crimen organizado aquella forma de delincuencia que se caracteriza por provenir de un grupo estructurado de dos o más personas, que exista durante cierto tiempo y que actúe concertadamente con el propósito de cometer uno o más delitos (Ley del Crimen Organizado y Delitos de Realización Compleja).

- Ley de Proscripción de Maras y Pandillas, Agrupaciones, Asociaciones y Organizaciones de Naturaleza Criminal. Esta ley es la base fundamental porque le da todo el imperativo a la corporación policial para desarticular a los grupos delincuenciales organizados en maras y pandillas, lo cual tipifica a los delincuentes organizados; pero ha faltado su aplicación de forma estratégica e integral para debilitarlos, ya que la realidad muestra que esos grupos evolucionan, tienen sus propios negocios ilícitos, marcan territorio y poder, al grado que la autoridad correspondiente no actúa eficientemente. Además cambian sus modus operandi y tácticas para que no les apliquen dicha ley. 
- Código Penal. Establece la pena a los sujetos infractores, lo cual es un reto para los operados y aplicadores de justicia, procesar a los sujetos con todas las evidencias y pruebas del delito, acción que recae en la Fiscalía General de la República (FGR) y I a Policía Nacional Civil (PNC), según el artículo 345 de dicho código.

- Ley Reguladora de las Actividades Relativas a las Drogas (2003). Es una normativa aplicable a las maras y pandillas, actualmente es otra forma de sustentación económica de estos grupos, la venta y distribución de droga a nivel local, y en algunos casos participan en los corredores del narcotráfico, brindando seguridad ya sea terrestre y marítima.

\subsection{Marco socioeconómico}

La actividad económica que desarrollan los pobladores en la zona rural, en su mayoría son personas que trabajan en las fincas (zona rural), otras lo hacen fuera de la zona, en trabajos de construcción y oficios domésticos. Existe un aproximado del $40 \%$ de personas que son empleados públicos y privados, con una escolaridad promedio de educación media.

En la entrada principal está ubicado el Centro Comercial Pasatiempo, y la Maxi Despensa, el primero alberga a un aproximado de 12 negocios en los cuales laboran varias personas de la zona.

Otras de las actividades que desarrolla la población de la residencial Los Chorros, es la atención de tiendas, pequeños negocios, cuyos propietarios son los mismos habitantes de la casa en donde está ubicada la tienda. Esta actividad la tienen como parte de subsistencia para los habitantes que no tienen un empleo formal, pero que se ven afectados con la renta que imponen los grupos delincuenciales organizados en maras o pandillas.

\subsection{Marco político}

El gobierno local mantiene coordinaciones con los actores claves y líderes comunales, entre los que se cuentan directivas comunales, presidentes de las ADESCO, líderes de equipos deportivos, presidentes de cooperativas, sacerdotes, pastores de iglesias, directores de centros educativos, representantes de otras instituciones gubernamentales, promotores de salud, Policía Nacional Civil. Ellos integran las mesas de trabajo tales como la mesa de seguridad ciudadana, la mesa de salud y medio ambiente; la mesa de juventud, cultura, recreación y deportes; la mesa de personas con discapacidad y la mesa de desarrollo local. 
La comuna del municipio de Colón contribuyó al desarrollo del proyecto de construcción habitacional residencial Los Chorros para hacer un total de 1619 casas de las cuales 140 están deshabitadas, porque sus habitantes emigraron hacia otros lugares. Estas casas abandonadas actualmente son utilizadas por la mara para esconderse de las autoridades o reunirse para planificar hechos delictivos.

La residencial Los Chorros fue creada por la necesidad de ofrecer alternativas de vivienda a la población; por la ubicación geográfica es una zona del país con más fábricas de maquilas, generándose un polo de desarrollo industrial y económico al abrirse fuentes de empleo, situación que también atrae a los miembros de la mara Salvatrucha MS para crear una agrupación o clica de delincuentes para mantener sus operaciones delincuenciales y sembrar el temor al ciudadano honesto y trabajador.

\subsection{Marco conceptual}

Los grupos delincuenciales configurados en las organizaciones de las maras son evolutivos, quiere decir que desde sus inicios fueron creando jerarquía, para mantener orden, respeto y control entre sus miembros, sectores y zonas.

\section{Características de los pandilleros actuales:}

- No manifiestan públicamente el orgullo de pertenecer a la mara.

- Se establecen y defienden un territorio geográfico para cometer hechos delictivos.

- Están abandonando el tatuaje, el caló y su mímica particular.

- Mayor movilidad territorial-migración interna y externa.

- Se les considera una organización transnacional.

- Endurecimiento de los criterios de selección y de las reglas para evitar deserciones.

- Funcionan como una estructura jerárquica con liderazgos bien definidos.

- Ejercen mayor uso de la violencia, participan en hechos delictivos con características de crimen organizado y por consiguiente su barbarie.

- Tienen acceso a medios y recursos que han complejizado su accionar delincuencial. 
- Usan armas de fabricación industrial y legalizadas, de grueso calibre y de uso privativo del Ejército (Blog Morales Ortiz, 2009).

Líder internacional: Las pandillas están conectadas con la mafia mexicana, que dirige el tráfico de drogas y armas, y se encuentra en los Estados Unidos de Norteamérica.

Líderes nacionales o Ranfla Nacional: Está compuesta por 13 miembros, quienes se encuentran en prisión, asimismo estos integrantes son llamados los 13 discípulos, todos tienen voz y voto en las decisiones y dan las órdenes a toda la pandilla de una forma jerárquica, son los que dan la autorización si alguna clica o programa solicita realizar alguna acción delincuencial.

Encargados de programa en prisión: Son los que coordinan las acciones delictivas con los encargados de sus programas en libertad y reciben órdenes de los 13 discípulos, de las acciones que realizarán a nivel penitenciario y en libertad, integrados en los programas de la MS.

Encargados de programa en libertad: Estos reciben las órdenes de los encargados de programa que se encuentran en prisión para llevarlas a cabo e informan de los resultados obtenidos, convocan a los meeting (reuniones) a todos los encargados y corredores de clicas.

Encargados y corredores de clicas: Estos reciben las órdenes para ejecutarlas en sus territorios y llevar a cabo los hechos delictivos que se les han misionado y son quienes mantienen el control para que se ejecuten las reglas establecidas.

Sicarios o gatilleros: Son aquellos delincuentes designados por la pandilla (clica) para cometer diferentes delitos, ya sea en su zona de operación o a otras zonas donde se les ordene.

Extorsionista: Es el pandillero o integrante, que se encarga de recolectar el dinero producto de las extorsiones exigidas a la población (transporte público, comercio, ventas informales, entre otros).

Drogas o "pucher": Son pandilleros designados por el jefe de la clica para la venta de la droga (crack, marihuana), quienes deben de rendir cuentas al jefe de clica donde opere; en algunos casos el encargado de esta actividad es el jefe de la clica.

Soldados o miembros: Son los integrantes de la pandilla que no tienen ningún cargo o rango, sino que materializan las órdenes que reciben de los jefes de las clicas. 


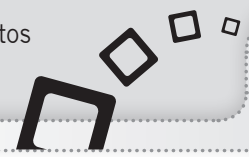

Poste: Es un observador que hace vigilancia a autoridades y posibles víctimas. Puede ser una persona de cualquier edad y sexo, en su mayoría no han pasado el proceso de ingreso a la pandilla y su misión principal es mantener informados a los grupos delincuenciales.

Colaboradores: Son personas que, de una u otra forma, le sirven a la pandilla, informándole de algún hecho o facilitando medios para realizar las diferentes acciones que esta realiza o escondiéndole las armas de fuego que utiliza (estas personas simpatizan con ellos); en algunos casos son familiares que apoyan de una manera obligada, mediante amenazas o por afinidad.

Chequeo: Son miembros que se encuentran en la fase de vigilancia dentro del grupo. Deben cumplir diferentes condiciones para ser aceptados dentro de la pandilla.

Maras: Conjunto de personas organizadas en una estructura con fines delictivos, que se establecen en un territorio determinado.

El Estado: "Es la sociedad política y jurídicamente organizada capaz de imponer la autoridad de la Ley en el interior y afirmar su personalidad y responsabilidad frente a las similares del exterior". Otra definición de Estado es "una organización social constituida en un territorio propio, con fuerza para mantenerse en él, e imponer dentro de él un poder supremo de ordenación y de imperio, poder ejercido por aquel elemento social que en cada momento asume la mayor fuerza política" (Osorio, 1997).

\section{Planteamiento del problema}

\subsection{Problema general}

La falta de estrategias integrales de impacto en materia de seguridad, para desarticular a los grupos delincuenciales de los territorios delimitados, ha contribuido a que estos desarrollen un nivel de influencia y poder, sobre los habitantes de la residencial Los Chorros, generando un ambiente de inseguridad y terror.

\subsection{Problemas específicos}

\section{Problema específico 1}

La falta de estrategias integrales de impacto en materia de seguridad, para desarticular a los grupos delincuenciales de los territorios delimitados por ellos en forma ilegal y violenta, les ha permitido mantener un nivel de organización de mando vertical, lo que establece un mayor grado de control y poder en sus miembros para cometer sus actividades ilícitas, 
e imponen el miedo y la sumisión sobre la población que habita en esos territorios.

\section{Problema específico 2}

Los grupos delincuenciales marcan sus límites territoriales para operar libremente, cometer sus actos ilícitos de índole económica, generando impunidad y temor.

\section{Problema específico 3}

Los grupos delincuenciales utilizan armas de fuego de grueso calibre, armas blancas, granadas, uniformes similares a la policía y Fuerza Armada, para cometer sus ilícitos y tienen como colaboradores a familiares y residentes de la comunidad.

\section{Objetivos}

\subsection{Objetivo general}

Proponer estrategias integrales que coadyuven a la erradicación de los grupos delincuenciales que operan en la residencial Los Chorros, cantón Las Angosturas, municipio de Colón del departamento de La Libertad.

\subsection{Objetivos específicos}

a. Identificar la estructura organizativa de los grupos delincuenciales que operan en la residencial Los Chorros, cantón Las Angosturas, municipio de Colón, departamento de La Libertad.

b. Conocer los límites geográficos de actuación de los grupos delincuenciales de la zona en estudio.

c. Establecer el modus operandi y el apoyo brindado por la estructura y sus colaboradores.

d. Proponer estrategias para el rescate de los territorios dominados por las maras en la residencial Los Chorros, cantón Las Angosturas, municipio de Colón, departamento de La Libertad. 


\section{Operacionalización de variables}

\subsection{Operacionalización de los problemas específicos}

Tabla 1. Operacionalización de los problemas específicos

\begin{tabular}{|c|c|c|c|c|}
\hline $\begin{array}{l}\text { Objetivos } \\
\text { específicos }\end{array}$ & $\begin{array}{l}\text { Problemas } \\
\text { específicos }\end{array}$ & Variables & $\begin{array}{l}\text { Definición } \\
\text { conceptual }\end{array}$ & Indicadores \\
\hline $\begin{array}{l}\text { (0E1) } \\
\text { Identificar la } \\
\text { estructura } \\
\text { organizativa } \\
\text { de los grupos } \\
\text { delincuenciales } \\
\text { que operan en la } \\
\text { residencial Los } \\
\text { Chorros, cantón } \\
\text { Las Angosturas, } \\
\text { municipio de Colón, } \\
\text { departamento de La } \\
\text { Libertad. }\end{array}$ & $\begin{array}{l}\text { (PE1) } \\
\text { La falta de estrategias } \\
\text { integrales de impacto en } \\
\text { materia de seguridad, } \\
\text { para desarticular a los } \\
\text { grupos delincuenciales } \\
\text { de los territorios } \\
\text { delimitados les ha } \\
\text { permitido mantener un } \\
\text { nivel de organización } \\
\text { de mando vertical, lo } \\
\text { que establece un mayor } \\
\text { grado de control y poder } \\
\text { en sus miembros para } \\
\text { cometer sus actividades } \\
\text { ilícitas. }\end{array}$ & $\begin{array}{l}\text { VI (X) La falta } \\
\text { de estrategias } \\
\text { integrales de } \\
\text { impacto en materia } \\
\text { de seguridad } \\
\text { para desarticular } \\
\text { a los grupos } \\
\text { delincuenciales } \\
\text { de los territorios } \\
\text { delimitados. } \\
\\
\text { VD (Y) Les ha } \\
\text { permitido mantener } \\
\text { un nivel de } \\
\text { organización de } \\
\text { mando vertical, } \\
\text { lo que establece } \\
\text { un mayor grado } \\
\text { de control y poder } \\
\text { en sus miembros } \\
\text { para cometer sus } \\
\text { actividades ilíitas. }\end{array}$ & $\begin{array}{l}\text { El Estado } \\
\text { constitucionalmente } \\
\text { desarrolla políticas } \\
\text { públicas, y tiene } \\
\text { la facultad de } \\
\text { integrar actores de } \\
\text { la sociedad a fin } \\
\text { de solucionar los } \\
\text { problemas sociales } \\
\text { de forma eficaz } \\
\text { y para el bien común. } \\
\\
\text { Las pandillas tienen } \\
\text { un jefe a nivel } \\
\text { nacional, jefe de } \\
\text { programa y clica } \\
\text { (liderada por un } \\
\text { palabrero), quien } \\
\text { dirige a varios } \\
\text { miembros que tienen } \\
\text { funciones específicas. } \\
\text { El jefe de la clica } \\
\text { tiene el poder de } \\
\text { mando sobre sus } \\
\text { miembros y da } \\
\text { cumplimiento a } \\
\text { las órdenes del } \\
\text { programa para } \\
\text { cometer homicidios, } \\
\text { extorsiones, robos } \\
\text { y enfrentar a las } \\
\text { autoridades. }\end{array}$ & $\begin{array}{l}\text { (X1) Identificación de } \\
\text { actores locales para las } \\
\text { acciones en la solución } \\
\text { de los problemas } \\
\text { sociales. } \\
\\
\text { (X2) Identificar líder } \\
\text { del programa y } \\
\text { clica. Jefe, soldados, } \\
\text { gatilleros, extorsionistas, } \\
\text { colaboradores, } \\
\text { distribuidores de droga } \\
\text { y a quienes reclutan } \\
\text { jóvenes. } \\
\\
\text { (Y1) Acciones de } \\
\text { prevención en centros } \\
\text { escolares. }\end{array}$ \\
\hline
\end{tabular}




\begin{tabular}{|c|c|c|c|c|}
\hline $\begin{array}{c}\text { Objetivos } \\
\text { específicos }\end{array}$ & $\begin{array}{l}\text { Problemas } \\
\text { específicos }\end{array}$ & Variables & $\begin{array}{l}\text { Definición } \\
\text { conceptual }\end{array}$ & Indicadores \\
\hline $\begin{array}{l}\text { (0E2) } \\
\text { Conocer los límites } \\
\text { geográficos } \\
\text { de actuación } \\
\text { de los grupos } \\
\text { delincuenciales de la } \\
\text { zona en estudio. }\end{array}$ & $\begin{array}{l}\text { (PE2) } \\
\text { Los grupos } \\
\text { delincuenciales } \\
\text { marcan sus límites } \\
\text { territoriales para } \\
\text { operar libremente, } \\
\text { cometer sus actos } \\
\text { ilícitos patrimoniales } \\
\text { y generar impunidad } \\
\text { y temor. }\end{array}$ & $\begin{array}{l}\text { VI (X) Grupos } \\
\text { delincuenciales limitan } \\
\text { sus territorios para } \\
\text { operar libremente en } \\
\text { el cometimiento de sus } \\
\text { actos ilícitos de índole } \\
\text { económico. } \\
\text { VD (Y) Generan } \\
\text { impunidad y } \\
\text { terror al ocultarse } \\
\text { clandestinamente. }\end{array}$ & $\begin{array}{l}\text { Los miembros de los } \\
\text { grupos delincuenciales } \\
\text { al cometer homicidios, } \\
\text { extorsiones, } \\
\text { robos, se ocultan } \\
\text { clandestinamente en } \\
\text { las zonas ocupadas } \\
\text { a fin de que no } \\
\text { sean detectados y } \\
\text { capturados por la } \\
\text { autoridad. } \\
\text { Para mantener la } \\
\text { clandestinidad } \\
\text { generan amenazas } \\
\text { a los habitantes } \\
\text { de asesinarlos si } \\
\text { denuncian ante la } \\
\text { policía. } \\
\text { Infunden terror a } \\
\text { los habitantes, al } \\
\text { cometer homicidios } \\
\text { con características de } \\
\text { barbarie y generar un } \\
\text { ambiente de miedo e } \\
\text { inseguridad. } \\
\text { Utilizan a sus familiares, } \\
\text { para que funcionen } \\
\text { como vigilantes y } \\
\text { avisan cuando llegan } \\
\text { las autoridades. }\end{array}$ & $\begin{array}{l}\text { (X1) Establecer un } \\
\text { puesto de policía } \\
\text { comunitaria. } \\
\text { (X1) Realizar } \\
\text { investigaciones de los } \\
\text { delitos contra la vida, } \\
\text { salud y patrimoniales. } \\
\text { (Y1) Identificar, } \\
\text { marcar y controlar las } \\
\text { casas abandonadas y } \\
\text { usurpadas. } \\
\text { (Y2) Gestionar y } \\
\text { desarrollar programas } \\
\text { de prevención de la } \\
\text { violencia con actores } \\
\text { locales, iglesia, } \\
\text { alcaldía, empresa } \\
\text { privada, ONG, centros } \\
\text { educativos. }\end{array}$ \\
\hline
\end{tabular}




\begin{tabular}{|c|c|c|c|c|}
\hline $\begin{array}{l}\text { Objetivos } \\
\text { específicos }\end{array}$ & $\begin{array}{l}\text { Problemas } \\
\text { específicos }\end{array}$ & Variables & $\begin{array}{l}\text { Definición } \\
\text { conceptual }\end{array}$ & Indicadores \\
\hline $\begin{array}{l}\text { (0E3) } \\
\text { Establecer el } \\
\text { modus operandi } \\
\text { (forma de } \\
\text { cometer los } \\
\text { delitos) y el apoyo } \\
\text { brindado por sus } \\
\text { colaboradores }\end{array}$ & $\begin{array}{l}\text { (PE3) } \\
\text { Los grupos delincuenciales } \\
\text { utilizan armas de fuego } \\
\text { de grueso calibre, armas } \\
\text { blancas, granadas, } \\
\text { uniformes similares a la } \\
\text { Policía y Fuerza Armada, } \\
\text { para cometer sus ilícitos y } \\
\text { tienen como colaboradores } \\
\text { a familiares y residentes de } \\
\text { la comunidad. }\end{array}$ & $\begin{array}{l}\text { VI (X) Grupos } \\
\text { delincuenciales utilizan } \\
\text { armas de grueso calibre, } \\
\text { armas blancas, granadas, } \\
\text { uniformes similares a la } \\
\text { Policía y Fuerza Armadas. } \\
\text { VD (Y) Tienen como } \\
\text { colaboradores a familiares } \\
\text { y residentes de la } \\
\text { comunidad. }\end{array}$ & $\begin{array}{l}\text { Con los dineros } \\
\text { obtenidos de } \\
\text { las extorsiones, } \\
\text { los grupos } \\
\text { delincuenciales } \\
\text { compran armas de } \\
\text { grueso calibre de uso } \\
\text { privativo de la FAES. } \\
\text { Compran en el } \\
\text { mercado uniformes } \\
\text { similares a los de la } \\
\text { Policía y FAES para } \\
\text { cometer sus delitos. } \\
\text { 0 los obtienen } \\
\text { bajo amenaza } 0 \\
\text { colaboración del } \\
\text { personal de la PNC } \\
\text { y FAES. } \\
\text { Los habitantes } \\
\text { que no colaboran } \\
\text { son amenazados } \\
\text { a muerte o } \\
\text { extorsionados por lo } \\
\text { que emigran a otros } \\
\text { lugares }\end{array}$ & $\begin{array}{l}\text { (X1) Aplicar las leyes } \\
\text { correspondientes } \\
\text { relativas a uniformes } \\
\text { y armas de fuego. } \\
\text { (X2) Gestionar a } \\
\text { través de la alcaldía } \\
\text { vedas de armas. } \\
\text { (Y1) Gestionar } \\
\text { programas integrales } \\
\text { sostenibles de } \\
\text { prevención para } \\
\text { rescatar a los niños/ } \\
\text { as y jóvenes en } \\
\text { riesgo. }\end{array}$ \\
\hline
\end{tabular}




\section{Tabla 2. Matriz de análisis de las variables cualitativas}

\begin{tabular}{|c|c|c|c|c|c|}
\hline Tema & $\begin{array}{l}\text { Planteamientos } \\
\text { del problema }\end{array}$ & Objetivos & $\begin{array}{l}\text { Problemas } \\
\text { específicos }\end{array}$ & Variables & Indicadores \\
\hline $\begin{array}{l}\text { Las estrategias de } \\
\text { recuperación por } \\
\text { parte del Estado } \\
\text { en los territorios } \\
\text { con presencia } \\
\text { delincuencial } \\
\text { y sus efectos } \\
\text { en el ambiente } \\
\text { que viven los } \\
\text { habitantes de la } \\
\text { residencial Los } \\
\text { Chorros, cantón } \\
\text { Las Angosturas, } \\
\text { municipio } \\
\text { de Colón, } \\
\text { departamento de } \\
\text { La Libertad. }\end{array}$ & $\begin{array}{l}\text { La implementación de } \\
\text { estrategias integrales } \\
\text { de impacto en materia } \\
\text { de seguridad por } \\
\text { parte del Estado, que } \\
\text { buscan desarticular } \\
\text { los grupos } \\
\text { delincuenciales, } \\
\text { podría ser un } \\
\text { mecanismo que } \\
\text { contribuiría a su } \\
\text { erradicación y a } \\
\text { generar de esa } \\
\text { manera un ambiente } \\
\text { de tranquilidad y } \\
\text { armonía social en } \\
\text { los ciudadanos de } \\
\text { la residencial Los } \\
\text { Chorros, cantón } \\
\text { Las Angosturas, } \\
\text { municipio de Colón, } \\
\text { departamento de La } \\
\text { Libertad. }\end{array}$ & $\begin{array}{l}\text { Proponer estrategias } \\
\text { integrales } \\
\text { para erradicar } \\
\text { a los grupos } \\
\text { delincuenciales } \\
\text { que operan en la } \\
\text { residencial Los } \\
\text { Chorros, cantón } \\
\text { Las Angosturas, } \\
\text { municipio de Colón } \\
\text { del departamento } \\
\text { de La Libertad. } \\
\text { Objetivos específicos } \\
\text { Identificar la } \\
\text { estructura } \\
\text { organizativa } \\
\text { de los grupos } \\
\text { delincuenciales } \\
\text { que operan en la } \\
\text { residencial Los } \\
\text { Chorros, cantón } \\
\text { Las Angosturas, } \\
\text { municipio de Colón, } \\
\text { departamento de La } \\
\text { Libertad. } \\
\text { Conocer los límites } \\
\text { geográficos } \\
\text { de actuación } \\
\text { de los grupos } \\
\text { delincuenciales de la } \\
\text { zona en estudio. } \\
\text { colaboradores } \\
\text { Establecer el modus } \\
\text { operandi (forma } \\
\text { de cometer los } \\
\text { delitos) y el apoyo } \\
\text { brindado por sus } \\
\text { ond }\end{array}$ & $\begin{array}{l}\text { (PE) La falta } \\
\text { de estrategias } \\
\text { integrales de } \\
\text { impacto en } \\
\text { materia de } \\
\text { seguridad, para } \\
\text { desarticular } \\
\text { a los grupos } \\
\text { delincuenciales } \\
\text { de los territorios } \\
\text { delimitados les } \\
\text { ha permitido } \\
\text { mantener un } \\
\text { nivel de } \\
\text { organización } \\
\text { de mando } \\
\text { vertical, lo que } \\
\text { establece un } \\
\text { mayor grado de } \\
\text { control y poder } \\
\text { en sus miembros } \\
\text { para cometer } \\
\text { sus actividades } \\
\text { ilícitas. }\end{array}$ & $\begin{array}{l}\text { (VI) Falta de } \\
\text { estrategias } \\
\text { integrales de } \\
\text { impacto en } \\
\text { materia de } \\
\text { seguridad para } \\
\text { desarticular } \\
\text { los grupos } \\
\text { delincuenciales, } \\
\text { de los territorios } \\
\text { delimitados. } \\
\text { (VD) Mantener } \\
\text { un nivel de } \\
\text { organización de } \\
\text { mando vertical, lo } \\
\text { que establece un } \\
\text { mayor grado de } \\
\text { control y poder } \\
\text { en sus miembros } \\
\text { para cometer } \\
\text { sus actividades } \\
\text { ilícitas. }\end{array}$ & $\begin{array}{l}\text { Falta de } \\
\text { estrategias } \\
\text { integrales de } \\
\text { seguridad. } \\
\text { Grupos } \\
\text { delincuenciales. } \\
\text { Control de } \\
\text { territorios para } \\
\text { operar. } \\
\text { Inseguridad en } \\
\text { los habitantes } \\
\text { por amenazas } \\
\text { de muerte y } \\
\text { extorsiones. } \\
\text { Temor de los } \\
\text { habitantes a } \\
\text { denunciar actos } \\
\text { delictivos. } \\
\text { Desconfianza de } \\
\text { los habitantes } \\
\text { hacia los } \\
\text { miembros de la } \\
\text { PNc. } \\
\text { Deficiente } \\
\text { aplicación de la } \\
\text { ley en los grupos } \\
\text { delincuenciales. }\end{array}$ \\
\hline
\end{tabular}




\section{Metodología de la investigación}

\subsection{Tipo de investigación}

La investigación es de tipo cualitativo ya que se buscó argumentar, sobre la opinión, producto de informaciones obtenidas de diferentes personas, quienes comunicaron sobre las situaciones, circunstancias o estado del problema en estudio. La base del proceso de la investigación cualitativa se condicionó desde la función operativa de la técnica de los actores claves que es aplicada mediante entrevistas a los principales actores de la residencial Los Chorros.

Además de la investigación cualitativa, también se privilegió la técnica de la investigación documental, la técnica de análisis y síntesis de documentos que tienen relación con la situación actual del problema de inseguridad delincuencial. Hay que destacar que el fenómeno de los grupos delincuenciales ha sido sujeto de estudio desde los años noventa, lo cual permite abordar varios autores, investigaciones, conferencias y congresos, que en forma articulada, han fortalecido el estudio desarrollado.

\subsection{Población}

La población se estima en unas 4500 personas entre adultos, jóvenes, niños y niñas, aunque esta cifra varía por tratarse de un sector de donde la gente ha emigrado a otras zonas por la delincuencia y es habitado por nuevos vecinos. La población se desglosa de la siguiente manera:

- Niños, niñas y adolescentes: aproximadamente 2120 menores de 18 años.

- Mujeres: alrededor de 975 ente los 18 y 60 años y 325 mayores de 60 años.

- Hombres: rondan los 800 entre los 18 y 60 años y 247 mayores de los 60 años.

\subsubsection{Determinación del tamaño de la muestra}

Para la obtención de la información del estudio sobre los grupos delincuenciales, se aplicó un instrumento de entrevista a los principales actores locales estratégicos con incidencia en la residencial Los Chorros, de manera aleatoria, a fin de obtener los elementos claves que permitieron corroborar los problemas planteados en la investigación y establecer una realidad más concreta del fenómeno (ver tabla 3). 


\section{Tabla 3. Sujetos entrevistados}

\begin{tabular}{|l|c|}
\hline Sujetos & Número \\
\hline Alcalde municipal de Colón & 1 \\
\hline Referente de la comunidad & 1 \\
\hline Jefe de la base móvil de la PNC & 1 \\
\hline Directora del centro escolar residencial Los Chorros & 1 \\
\hline Jefe de la subdelegación de la PNC del municipio de Colón & 1 \\
\hline $\begin{array}{l}\text { Pastor de la iglesia evangélica Tabernáculo Bíblico Bautista } \\
\text { Amigos de Israel "Los Chorros" }\end{array}$ & 1 \\
\hline Juez Segundo de Paz, Colón & 1 \\
\hline $\begin{array}{l}\text { Doctora en medicina de la unidad comunitaria de salud } \\
\text { familiar El Botoncillal }\end{array}$ & 1 \\
\hline $\begin{array}{l}\text { Directora del colegio Consuelo de Carmen Coto, residencial } \\
\text { Los Chorros }\end{array}$ & 1 \\
\hline $\begin{array}{l}\text { Jefe del Departamento de Inteligencia Policial, Delegación } \\
\text { Lourdes }\end{array}$ & 1 \\
\hline $\begin{array}{l}\text { Jefe del Departamento de Investigaciones PNC, Delegación } \\
\text { Lourdes }\end{array}$ & 1 \\
\hline \begin{tabular}{l} 
Total \\
\hline
\end{tabular} & 11 \\
\hline
\end{tabular}

Fuente: Elaboración propia.

\subsubsection{Técnicas e instrumentos}

A fin de seleccionar la muestra para el presente estudio, se administró una entrevista con preguntas abiertas a los actores claves, para el mejor levantamiento de información y para obtener un dato más objetivo sobre la problemática de los grupos delincuenciales, además de observar el comportamiento de la población para conocer cuál es la percepción de seguridad/inseguridad y confianza/temor que generan los grupos delincuenciales, en la residencial Los Chorros.

El instrumento es un cuestionario de 15 preguntas abiertas, relacionadas con la situación problemática del fenómeno en estudio; dicho instrumento se estructuró partiendo de la operacionalización de los problemas 
específicos y de la matriz de análisis de las variables cualitativas (ver tablas 1 y 2).

Este cuestionario se aplicó a los principales actores estratégicos de residencial Los Chorros para obtener la información relacionada con el problema de los grupos delincuenciales, lo cual permitió desarrollar un análisis de la situación de inseguridad que viven los habitantes (ver anexo 8 "Instrumento de entrevista").

\subsubsection{Procedimiento de recolección de la información}

El equipo investigador contactó a los actores locales antes descritos, con quienes se abordó la técnica de entrevista dirigida y se aplicó el instrumento; tomando en cuenta que dichos actores residen, trabajan o realizan alguna actividad social, económica, educativa, de salud, de seguridad, espiritual y de desarrollo comunal, en la zona donde se realizó la investigación y por lo tanto, no solo conocen el territorio, sino que tienen alguna autoridad, influencia o incidencia en la residencial.

Para la aplicación del instrumento de las entrevistas, se abordó a los actores locales de forma directa en sus oficinas o lugares de trabajo en el sector de la residencial Los Chorros y Lourdes Colón, entre ellos: referente comunitario, líderes de la iglesia y alcaldía, jefes policiales, Juzgado de Paz, directora del centro escolar y también la de un colegio privado, promotor social de salud, a quienes se les aplicó el instrumento de 15 preguntas de tipo abiertas, relacionadas con los grupos delincuenciales que operan en la residencial IOs Chorros de Lourdes Colón.

\section{Análisis e interpretación de resultados}

\subsection{Análisis de entrevistas}

\subsubsection{Problema específico 1}

Al redactar el problema se plantea que "la falta de estrategias integrales de impacto en materia de seguridad, para desarticular a los grupos delincuenciales de los territorios delimitados les ha permitido mantener un nivel de organización de mando vertical, lo que establece un mayor grado de control y poder en sus miembros para cometer sus actividades ilícitas". Ante ello, los actores claves de la residencial Los Chorros, a quienes se les administró el instrumento de entrevista con preguntas abiertas, manifestaron que, en su mayoría, conocen de la existencia de grupos delincuenciales identificados como Mara Salvatrucha (MS), que es la que domina la zona geográfica estudiada; en menor cuantía, los actores claves aseguraron no conocer sobre estos grupos. También, se tiene como resultado la identificación de miembros de la estructura y líderes, lo que podría contribuir a la desarticulación de ese grupo. 
Además, los entrevistados confirman que los grupos delincuenciales cometen los delitos siguientes: homicidios agravados, robo agravado, extorsiones, tráfico ilícito de drogas, tenencia y portación de arma de fuego ilegal, amenazas, hurto, contra el patrimonio, usurpación de propiedad privada, privación de libertad y violación. La ejecución de todos estos delitos confirman el nivel delictivo y organizativo que mantienen los grupos delincuenciales, y, en consecuencia, mantienen a la población de la residencial Los Chorros, con un nivel de inseguridad y temor por las amenazas constantes que a diario viven esos habitantes.

Lo anterior confirma que, hasta la fecha, no existen estrategias integrales para desarticular a esos grupos delincuenciales, ya que cada vez se ven más fortalecidos y ejercen un control territorial, principalmente en la zona sujeto de estudio de la residencial Los Chorros.

Otro indicador importante es que los actores claves confirman que conocen programas de prevención de la violencia dirigidos a niños y niñas, que se implementan en los centros escolares, desarrollados por la PNC y la Unidad de Salud, lo que demuestra que las acciones de prevención son muy limitadas y aisladas sin continuidad. No existe un enfoque ni un compromiso integral de las instituciones del gobierno, ni del Comité Intersectorial de Prevención de la Violencia y Delincuencia para neutralizar a los grupos delincuenciales. Los niños y niñas de los centros escolares, a pesar de conocer sobre estos programas, son vulnerables ante esos grupos, ya que ejercen amenazas de muerte y los niños y niñas son obligados a ingresar a los grupos delincuenciales, y en algunos casos los padres de familia por temor no permiten que sus hijos asistan a clases, contribuyendo a la deserción escolar.

\subsubsection{Problema específico 2}

Otra de las problemáticas sujeto de análisis, es que "los grupos delincuenciales marcan sus límites territoriales, para operar libremente, en el cometimiento de sus actos ilícitos de índole económico, generando impunidad y temor". Al respecto, al consultar con los actores claves sobre la necesidad de instalación de un puesto policial permanente en residencial Los Chorros, en su totalidad manifestó que sí, argumentando que la zona es peligrosa y que se deberá dominar a los grupos delincuenciales, recuperando territorios, dando mayor seguridad a los habitantes de la comunidad, disminuyendo los delitos, desarrollando más patrullajes, e incrementando el personal policial.

Todo esto confirma que la zona es altamente vulnerable y que los grupos delincuenciales mantienen un nivel de control en la zona. Lo anterior es oportuno para que las autoridades correspondientes ejecuten un plan de acción integral en materia de seguridad que coadyuve a desarticular los 


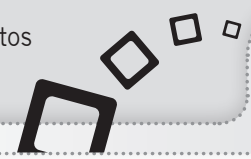

grupos delincuenciales en las zonas que son controladas y delimitadas para sus acciones ilícitas.

Un indicador importante es que los actores conocen que la PNC ha realizado investigaciones para la captura de los grupos delincuenciales, pero que no ha sido suficiente, ya que se necesitan mayores esfuerzos en la erradicación en los delitos de usurpación de viviendas, extorsiones y amenazas. Lo anterior indica que las acciones realizadas por la PNC no han sido suficientes para neutralizar a los grupos delincuenciales, ya que es necesario desarrollar acciones integrales, que conlleven a recuperar el territorio y a generar una nueva fase de convivencia ciudadana y que los habitantes puedan vivir en paz y armonía social.

Otro elemento a tomar en cuenta es que los grupos delincuenciales marcan sus límites territoriales para operar libremente en sus acciones ilícitas. Asimismo los actores conocen de la existencia de casas abandonadas por sus propietarios, producto de amenazas y extorsión por los grupos delincuenciales; los entrevistados manifiestan que los delincuentes marcan su territorio y ejercen control, para convertir esas zonas en áreas operativas para infundir temor, y cometer sus acciones ilícitas, tales como la extorsión, que se ha convertido en un factor de sustentación económica, que fortalece a esos grupos, para comprar armas, vehículos, teléfonos, pagar abogados, establecer pequeños negocios para lavar el dinero, comprar drogas para el tráfico local y consumo, y comprar ropa para sus familiares y los miembros de la estructura.

En ese sentido, toma interés si los actores claves conocen que se han desarrollado programas en la comunidad, la mayor parte manifestó desconocer si se han dado o no, y un mínimo dijo que conoce algunos programas desarrollados bien sea por el Instituto de Estudios de la Mujer (CEMUJER), la empresa privada Holcim o la ONG Responsabilidad Social Empresarial (RSE), y otros realizados por la alcaldía municipal. Pero lo único que indican es que se desarrollan acciones aisladas, sin mayor impacto para erradicar el problema de los grupos delincuenciales; este escenario es importante tomar en cuenta en la planificación y ejecución de estrategias integrales de seguridad.

\subsubsection{Problema específico 3}

Al analizar la problemática sobre "los grupos delincuenciales que utilizan armas de fuego de grueso calibre, armas blancas, granadas, uniformes similares a los de la Policía y Fuerza Armada, para cometer sus ilícitos y tienen como colaboradores a familiares y residentes de la comunidad". Los actores en su mayoría manifestaron que conocen que los grupos delincuenciales utilizan arma de fuego, entre ellas, pistolas y armas blancas; los calibres más utilizados son $9 \mathrm{~mm}$ y $38 \mathrm{~mm}$ y AK-47 calibre 7.62, y 
granadas fragmentarias de uso militar; además, conocen que en algunas ocasiones los miembros de la estructura utilizan uniformes similares a los que usa la PNC y la Fuerza Armada (FAES), para cometer sus ilícitos, así se ratifica el nivel de violencia que los grupos delincuenciales realizan en la residencial Los Chorros para cometer hechos ilícitos

Los niveles de inseguridad que ejercen los grupos delincuenciales también se confirman con el control que desarrollan en los residentes y visitantes. Existen miembros de esas estructuras que están pendientes del ingreso de personas a las zonas controladas, quienes se hacen pasar como vendedores de fruta y menores de edad, pero en realidad hacen las funciones de "vigilantes", denominados "postes". Son los encargados de avisar a sus líderes y estos tienen la facultad de ordenar si los asesinan o solamente los amenazan, también tienen un nivel de incidencia tal que hasta han prohibido a los residentes organizarse en la asociación de desarrollo comunal (ADESCO), lo que genera temor en los habitantes.

Se consultó a los actores qué proponen para solventar el problema de inseguridad y erradicar a los grupos delincuenciales, y manifestaron lo siguiente: es necesario instalar una unidad policial con el apoyo de la alcaldía y ONG, con suficiente personal y equipo (vehículos, motos y bicicletas), local propio, intercomunicadores adecuados, propiciando el desarrollo de la filosofía de policía comunitaria, e instalar cámaras de videovigilancia y mantener el control del acceso principal de la residencial, organizar la asociación de desarrollo comunitaria (ADESCO), desarrollar un programa integral para niños y niñas, instalar talleres vocacionales, apoyo institucional por parte de la alcaldía municipal, recuperación de espacios públicos, desarrollar trabajos con los jóvenes y la familias, mayor patrullajes durante el día y la noche, levantamiento de información de los miembros de los grupos delincuenciales (postes, colaboradores, gatilleros, lideres, entre otros), desarrollo de programas psicológicos y deportivos.

Tales sugerencias demuestran la necesidad inmediata de la formulación de una estrategia integral en materia de seguridad, que permita desarticular a los grupos delincuenciales, tomando en cuenta que la mayoría de actores no conoce de programas integrales desarrollados hacia los jóvenes.

\subsection{Tabulación de análisis inductivo}

\subsubsection{Pregunta 1}

¿Conoce la existencia y el nombre con que se identifican los grupos delincuenciales en residencial Los Chorros?

De los actores claves, en su mayoría confirmaron conocer de los grupos delincuenciales, y los identifican como Mara Salvatrucha (MS), también los 
identifican como grupo que domina la zona de la residencial Los Chorros; además, identifican a la Clica Citi Vagos Locos Salvatruchos (CVLS), y Programa Libertad.

\subsubsection{Pregunta 2}

¿Conoce el nombre o los alias de los encargados o jefes de los grupos delincuenciales que operan en la residencial Los Chorros?

Los actores claves manifestaron que conocen sobre los nombres y alias de los jefes de las estructuras de los grupos delincuenciales, identificándolos como:

- P.C.A., alias Peter o Snupy, palabrero.

- J. G. C. D., alias Morro, gatillero.

- L. F. F. alias Gánster, Serio, Splinter, palabrero en La Libertad.

- M. A. A. C., alias Colocho, Mafioso, prófugo.

- J. F. Z., alias Risa, recluso en el penal.

- J. C. M. P., alias Snaper, recluso en un penal.

- L. A. M., alias Diablillo, recluso en un penal.

- M. A., alias Sney o mafioso.

\subsubsection{Pregunta 3}

¿Conoce el nombre o alias de los integrantes de los grupos delincuenciales que operan en la residencial Los Chorros?

En una mínima proporción, los actores locales confirman la identificación de los miembros de la estructura de los grupos delincuenciales, identificándose a los siguientes:

- C. A. A. F., alias Chele.

- G. A. R. C., alias Gato.

- G. A. V. B., alias Adonay.

- C. J. S. C.

- N. I. M. R., alias Nata. 
- W. A. S. M., alias Rolón.

- M. B. A. F.

- D. A. A. R., alias Demente, Tupo, Moreno (prófugo).

- $\quad$ E. A. A. Q., alias Splinter, alias Topo, Chato.

\subsubsection{Pregunta 4}

¿Conoce el tipo de delitos que cometen los grupos delincuenciales en la residencial Los Chorros (contra la vida, contra la salud o contra el patrimonio)?

En su mayoría, los actores locales conocen de los delitos que cometen los miembros de los grupos delincuenciales, identificando los siguientes:

- Según procesos penales, homicidio agravado.

- Robo agravado.

- Extorsión.

- Tráfico ilícito de drogas.

- Tenencia, portación o conducción ilegal o irresponsable de arma de fuego.

- Contra el patrimonio y hurto.

- Amenazas.

- Usurpación de propiedad privada.

- Consumo ambulante de drogas.

- Venta ilícita de drogas.

- Privación de libertad.

- Violación.

- Desaparición de personas. 


\subsubsection{Pregunta 5}

¿Conoce sobre el desarrollo de programas de prevención de la violencia y delincuencia dirigido a niñas/os en los centros escolares?

Al preguntar a los actores locales sobre el desarrollo de los programas de prevención, en su mayoría manifestaron conocer, identificando los siguientes:

- Programas de prevención con la Embajada de los EE. UU. administrados por el Departamento de Prevención de la PNC Lourdes.

- Programa GREAT (Educación, entrenamiento en resistencia a las pandillas) y de Valores, impartido por personal policial a niños y niñas en centros escolares.

- Educación vial.

- Prevención de delitos y salud preventiva por la unidad de salud.

- Grupos de médicos que imparten charlas de prevención de los diferentes tipos de violencia en el centro escolar.

- Prevención de delitos y liderazgo.

\subsubsection{Pregunta 6}

¿Conoce de programas desarrollados en beneficio a la comunidad de la residencial Los Chorros, tales como jornadas médicas, deportivas, culturales y educativas?

Los actores locales respondieron que conocen de programas en beneficio a la comunidad, señalando los siguientes:

- Jornadas médicas y charlas educativas de la ONG, Instituto de Estudios de la Mujer (CEMUJER).

- Actividades deportivas (torneos).

- Jornadas preventivas, toma de citología y controles infantiles.

- Presencia de la empresa privada con proyectos de la ONG Responsabilidad Social Empresarial (RSE).

- Apoyo de la municipalidad en deporte y fortalecimiento del centro escolar. 
- Dentro de la filosofía de policía comunitaria (FPC), han logrado la cooperación de la empresa Holcim, para que una vez por mes atienda con un equipo médico (un médico, una enfermera y una auxiliar) al grupo familiar de los alumnos y alumnas del centro escolar público.

\subsubsection{Pregunta 7}

¿Considera usted necesaria la instalación de un puesto policial permanente en residencial Los Chorros?

En su mayoría los actores locales, respondieron que es necesario instalar un puesto policial en la residencial, argumentando lo siguiente:

- Por considerar una zona muy peligrosa.

- Para mayor seguridad de los habitantes y bajar los delitos.

- Con suficientes policías y equipos.

- Para disuadir grupos de pandillas, y recuperar el territorio.

- Por mayor seguridad de la comunidad.

- Es necesario por el alto índice delincuencial.

- Por la cantidad de personas que residen y delitos que se ejecutan. No hay personal suficiente, es necesario un puesto.

- Desarrollar más patrullajes (se hace especial énfasis en esta sugerencia).

\subsubsection{Pregunta 8}

¿Considera usted si la PNC ha realizado investigaciones efectivas para la captura de los grupos delincuenciales en la residencial Los Chorros y por cuáles delitos?

La mayor parte de los actores locales manifiestan conocer que la PNC ha realizado investigaciones para capturar a los miembros de los grupos delincuenciales, argumentando lo siguiente:

- Operativo en febrero del año 2014, estructura desarticulada por la División Central de Investigaciones (DCl), 25 personas entre pandilleros y colaboradores.

- Ha realizado buen trabajo, se necesita más en la erradicación de usurpaciones, extorsiones y amenazas. 
- Por la falta de recursos es necesario fortalecer con más elementos policiales y equipo.

\subsubsection{Pregunta 9}

¿Conoce de la existencia de casas abandonadas por sus propietarios, producto de amenazas o acoso de los grupos delincuenciales en la residencial Los Chorros?

Al preguntarles a los actores claves sobre la existencia de casas abandonadas, producto de las amenazas de los grupos delincuenciales, la mayoría reveló conocer que hay habitantes de la zona que manifiestan que existen casas abandonadas producto de las amenazas y extorsiones por parte de los grupos delincuenciales; existen unas 125 viviendas abandonadas.

\subsubsection{Pregunta 10}

¿Conoce sobre el desarrollo de operativos y programas de veda y desarme de armas de fuego ejecutados por la PNC en residencial Los Chorros?

Los actores claves que vertieron opinión sí tienen conocimiento de operativos y programas de veda de armas, sin embargo, la mayoría los desconoce en profundidad; en una mínima parte, expresan que hubo una veda de armas en 2014.

\subsubsection{Pregunta 11}

¿Conoce si los grupos delincuenciales utilizan uniformes policiales o militares para cometer delitos en residencial Los Chorros?

En su mayoría, los actores claves, confirman no conocer, pero algunos expresan que han visto grupos en los contornos de la residencial, en especial, camino hacia Las Brisas y los sujetos se visten de forma similar a policías y soldados, para confundir a los residentes y víctimas amenazadas.

\subsubsection{Pregunta 12}

¿Considera usted que los grupos delincuenciales ejercen control en los residentes y visitantes de la residencial Los Chorros?

La mayoría de los actores respondieron que los grupos delincuenciales ejercen control en los residentes y visitantes, ya que observan a sus miembros, que están pendientes del ingreso de personas a las zonas controladas, que los sujetos de las estructuras se ubican en la entrada de la residencial y se hacen pasar como vendedores de frutas y personas que hacen las funciones de "postes" (vigilantes), en los pasajes y calles. 
También los grupos delincuenciales a través de menores de edad exigen las "rentas" y han amenazado a los habitantes, que no organicen la asociación de desarrollo comunal (ADESCO). La población por temor no denuncia las acciones delictivas.

\subsubsection{Pregunta 13}

¿Qué tipo de armas conoce usted que utilizan los grupos delincuenciales para cometer sus hechos delictivos?

La mayoría de los actores entrevistados, respondieron que conocen de la utilización de armas de fuego para cometer delitos, por parte de los grupos delincuenciales, entre las armas que señalan están: pistolas, armas de fuego $9 \mathrm{~mm}, 38 \mathrm{~mm}$, AK-47, granadas y armas blanca, lo que indica que estos grupos a través de estos medios cometen ilícitos, para generar temor en los habitantes.

\subsubsection{Pregunta 14}

¿Conoce de programas integrales dirigidos a jóvenes en riesgo gestionados y desarrollados por los actores locales en residencial Los Chorros?

La mayoría de actores claves, manifestaron que no conocen de programas integrales que hayan sido desarrollas a jóvenes, lo que indica que las acciones que se desarrollan son aisladas, que no existe un enfoque integral de todos los actores que tienen incidencia en los residentes de la residencial Los Chorros.

\subsubsection{Pregunta 15}

¿Qué sugerencia propone para solventar el problema de inseguridad y erradicar los grupos delincuenciales de la residencial Los Chorros?

Los actores claves de la residencial, expresaron con mucho interés, importantes sugerencias para resolver el problema de inseguridad y erradicar los grupos delincuenciales, proponiendo lo siguiente:

- La instalación de una subdelegación, con suficiente personal policial y equipo.

- Acercamiento de la policía comunitaria.

- Apoyo institucional de la alcaldía, para otorgar beneficios a los pobladores y charlas de prevención.

- Realizar trabajos con jóvenes y familias. 
- Proyectos sociales inclusivos (como talleres vocacionales, productivos, pequeños negocios).

- Un puesto de la PNC permanente y local propio, con más personal policial.

- Un programa integral para niños y niñas en el sector e instalar talleres vocacionales.

- Recuperación de espacios públicos.

- Control en acceso principal, cámaras de videovigilancia y sacar a los usurpadores.

- Organizar la comunidad en ADESCO.

- Asignación de vehículos, motos y bicicletas para la PNC y más patrullajes en la noche y día.

- Instalar una base de policía comunitaria con apoyo de la alcaldía, ONG.

- Levantamiento de información de pandilleros, postes y colaboradores.

\section{Hallazgos relevantes a problemas planteados}

- Existencia de grupos delincuenciales identificados como la Mara MS, Citi Vagos Locos Salvatruchos.

- Incidencia delictiva de múltiples delitos contra la vida y de carácter económico.

- Significativa cantidad de casas abandonadas, por temor a las maras.

- Se comprobó la delimitación de las zonas controladas por estos grupos.

- Los habitantes expresan sentir temor ante su presencia, lo cual no les permite colaborar con las autoridades.

- La tenencia, portación y conducción de armas de fuego por los mareros.

- La necesidad de la comunidad de que se les garantice la seguridad de su integridad personal y bienes patrimoniales y la protección de sus derechos. 
- La necesidad de erradicar la delincuencia y la recuperación de territorio controlado por esos grupos.

- Falta de estrategias integrales por parte del Estado central y local.

- Ausencia de programas sociales permanentes y sostenibles para los residentes.

- Alta percepción de inseguridad de los habitantes.

\section{Conclusiones y recomendaciones}

\subsection{Conclusiones}

1. No han existido estrategias integrales de recuperación por parte del Estado de los territorios ocupados por las pandillas, radicadas en residencial Los Chorros.

2. Las acciones desarrolladas por las instituciones del Estado y ONG han sido llevadas a cabo de manera aislada y cortoplacista.

3. Los planes de seguridad implementados por la Policía Nacional Civil, junto con las investigaciones realizadas, no han sido efectivos para erradicar la delincuencia y recuperar el territorio de la residencial Los Chorros.

4. Los grupos que operan en la residencial Los Chorros actúan libre e impunemente por la escasa presencia preventiva y represiva por parte de la corporación policial.

5. Las pandillas de la zona en estudio están organizadas, estructuradas jerárquicamente y armadas con armas de fuego para ejecutar sus delitos.

6. Los grupos de delincuentes cuentan con el apoyo de algunos habitantes de la residencial Los Chorros; lo cual les permite que sus acciones ilícitas sean ejecutadas sin ser detectados fácilmente. Las fuentes económicas de sostenibilidad provienen de las extorsiones, y demás delitos de carácter económico que cometen en las zonas controladas. 


\subsection{Recomendaciones}

1. Que el Departamento de Investigaciones (DIN) en coordinación con el Departamento de Inteligencia Policial (DIP) realicen investigaciones efectivas a fin de individualizar y comprobar las conductas criminales de la clica Mara Salvatrucha MS (clica Citi Vagos Locos Salvatruchos), de la residencial Los Chorros.

2. Establecer un puesto policial con el recurso humano y material necesarios (una patrulla, cuatro motocicletas y seis bicicletas), e implementar la filosofía de policía comunitaria.

3. Desarrollar un proyecto de cámaras de videovigilancia, en la residencial Los Chorros.

4. Fortalecer el CIPVD, ejecutar en coordinación con la comunidad de la residencial un plan de recuperación de territorios y desarrollo social de convivencia ciudadana, en dicha residencial.

5. Desarrollar una política periódica de veda de armas en el municipio incluyendo especialmente la residencial Los Chorros. 


\section{Bibliografía}

Blog Morales Ortiz. (2009). Las maras en El Salvador.

Código Penal. (1997). Recuperado de http://www.asamblea.gob.sv/epar lamento

Elsalvador.com (2 de diciembre de 2011). Pandillas intimidan en Lourdes por marero muerto al enfrentar PNC. Recuperado de http:// archivo.elsalvador.com/mwedh/ nota/nota_completa.asp?idCat= 47654\&idArt $=6433827$

Escobar Rivera, D. B. (2009). Como afectan las maras a la sociedad salvadoreña. Recuperado de http:// lasmarassalvadorenas. blogspot. com/2009/05/algunas-causas-dela-creacion-de-maras.html

Ley del Crimen Organizado y Delitos de Realización Compleja. (2007). Recuperado de http://www.asam blea.gob.sv/eparlamento

Ley de Proscripción de Maras y Pandillas, Agrupaciones, Asociaciones y Organizaciones de Naturaleza Criminal. (2010). Recuperado de http:// www.asamblea.gob.sv/eparlamento
Ley Reguladora de las Actividades Relativas a las Drogas. (2003). Recuperado de http://www.asamblea. gob.sv/eparlamento

Osorio, M. (1997). Diccionario de Ciencias Jurídicas y Políticas. Buenos Aires: Heliasta.

PNC. (2010a). Avance de Policía Comunitaria, subdelegación de la Policía Nacional Civil, PNC, de Lourdes Colón.

PNC. (2010b). Diagnóstico de la sub delegación de la PNC, de Lourdes Colón, departamento de La Libertad, año 2010.

PNC. (2012). Decomisos de armas a pandilleros. Departamento de Investigaciones de la PNC.

PNC. (s/f). Avance de la Policía Comunitaria, subdelegación Lourdes Colón, departamento de La Libertad.

PNC. (2014). Diagnóstico de la delincuencia de la subdelegación de la Policía Nacional Civil-PNC, Lourdes, Colón. 


\section{Glosario de abreviaturas}

MS 13. Mara Salvatrucha 13.

P18 St. Pandilla 18.

CAT. Centro Antipandillas Trasnacional.

FBI. Buró Federal de Investigación de los EE. UU.

DEA. Departamento de Administración de Drogas de EE. UU.

ICE. Oficina de Investigación de Inmigrantes de EE. UU.

ONG. Organizaciones no gubernamentales.

GREAT. Educación y Entrenamiento en Resistencia a las Pandillas.

PNC. Policía Nacional Civil.

GCAC. Grupo Conjunto de Apoyo a la Comunidad.

FPC. Filosofía de policía comunitaria.

FAES. Fuerza Armada de El Salvador.

RSE. Responsabilidad Social Empresarial.

ADESCO. Asociación de Desarrollo Social Comunal.

DCl. División Central de Investigaciones. 


\section{ANEXOS}

\section{Anexo 1. Zonas del país con presencia de maras y pandillas}

\section{MAPEO DE MUNICIPIOS IDENTIFICADOS CON PRESENCIA DE PANDILLAS EN EL SALVADOR}

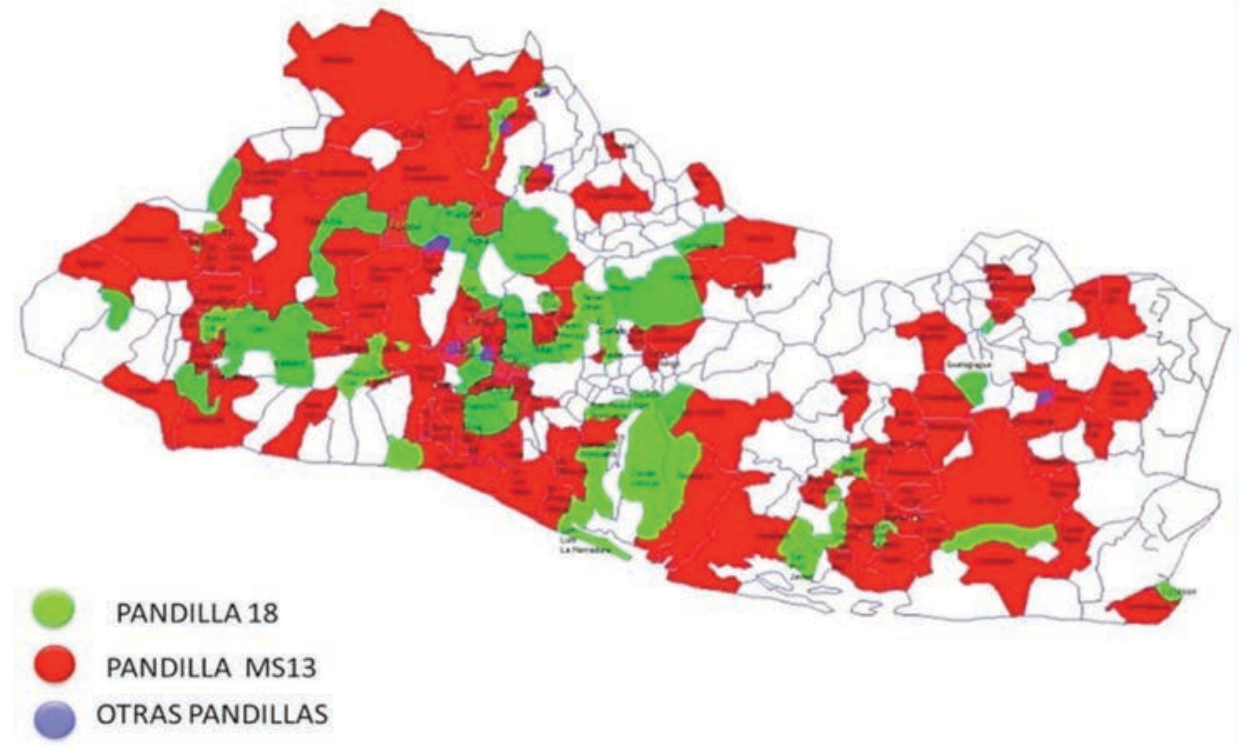

Fuente: Centro Antipandillas Trasnacional CAT-PNC.

\section{Anexo 2. Casas abandonadas}

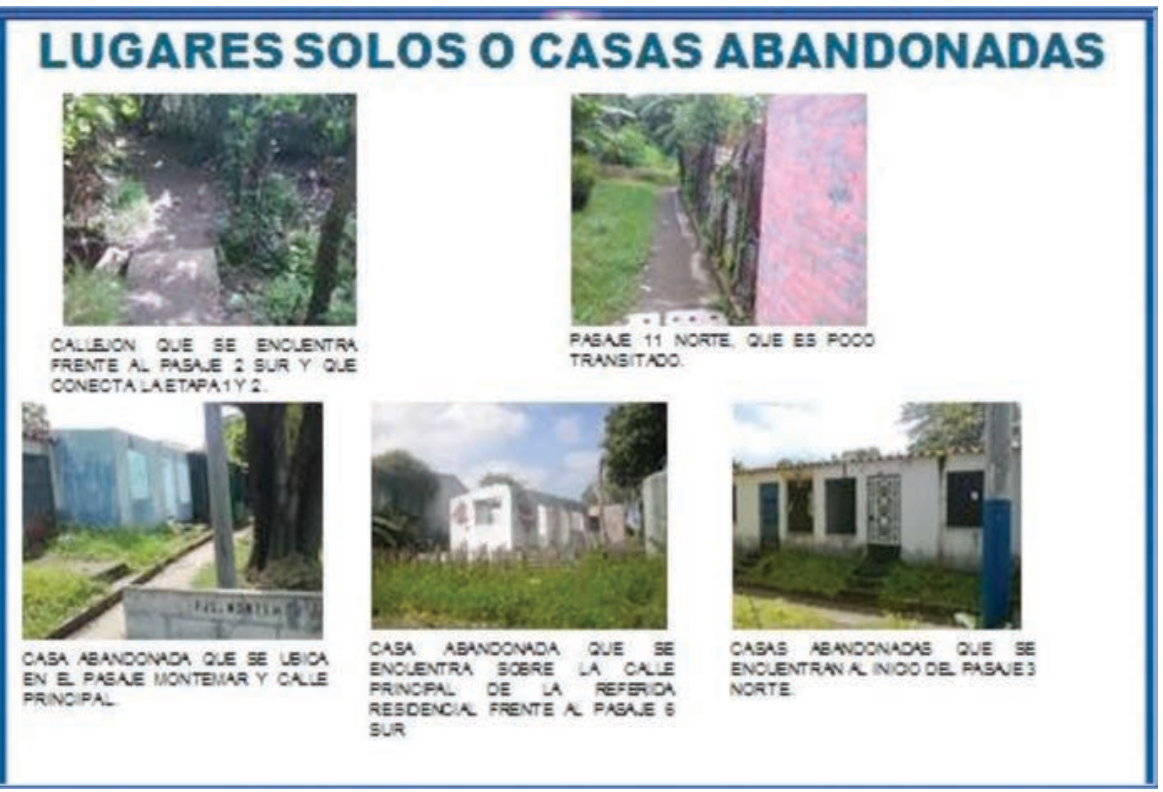

Fuente: Departamento de Investigaciones de la PNC. 


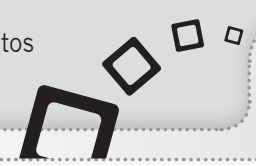

Anexo 3. Líneas estratégicas de los planes gubernamentales en materia de seguridad

Plan
Mano Dura $\left\{\begin{array}{l}\text { Rescatar los territorios usurpados por las pandillas. } \\ \text { - } \\ \text { - } \\ \text { Detener a los líderes de las pandillas. } \\ \text { - Eliminar el nexo con grupos delictivos. } \\ \text { - Incorporación de militares en tareas de seguridad pública. }\end{array}\right.$

Plan Súper
Mano Dura
2004-2009 $\left\{\begin{array}{l}\text { - } \text { Prevenir. } \\ \text { - Rehabilitar. } \\ \text { - Reinsertar a la vida laboral. }\end{array}\right.$

Plan de

Seguridad

Pública

2009-2014

Tregua 2012

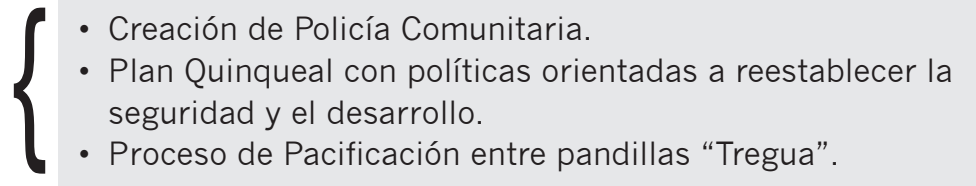

Plan de

Convivencia

Ciudadana

2014-2019

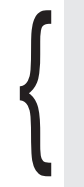

- Revertir el fenómeno de la violencia en el país.

- Fomentar la participación ciudadana.

- Relanzamiento de la Policía Comunitaria.

- Consejo Nacional de Seguridad Ciudadana y Convivencia.

Fuente: Elaboración propia. 


\section{Anexo 4. Delimitación del municipio de Colón}

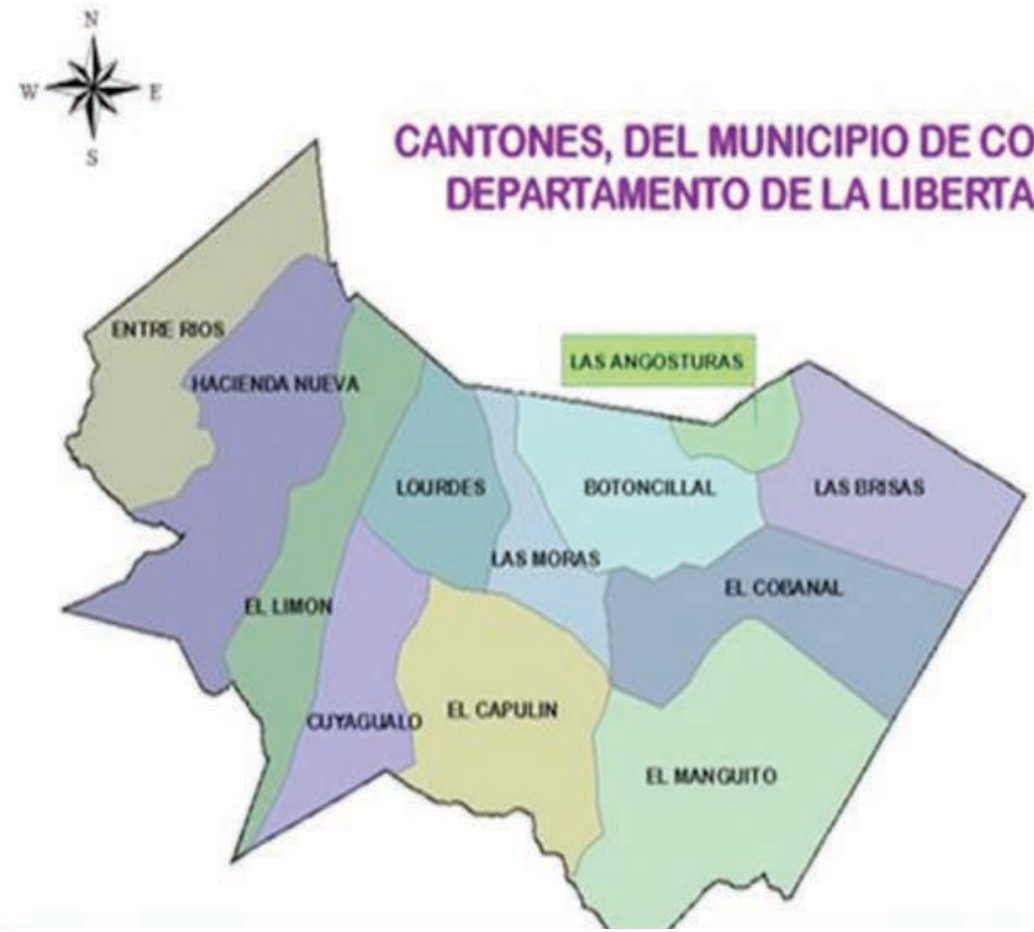

Fuente: Departamento de Investigaciones de la PNC

\section{Anexo 5. Ubicación geográfica de la residencial Los Chorros}

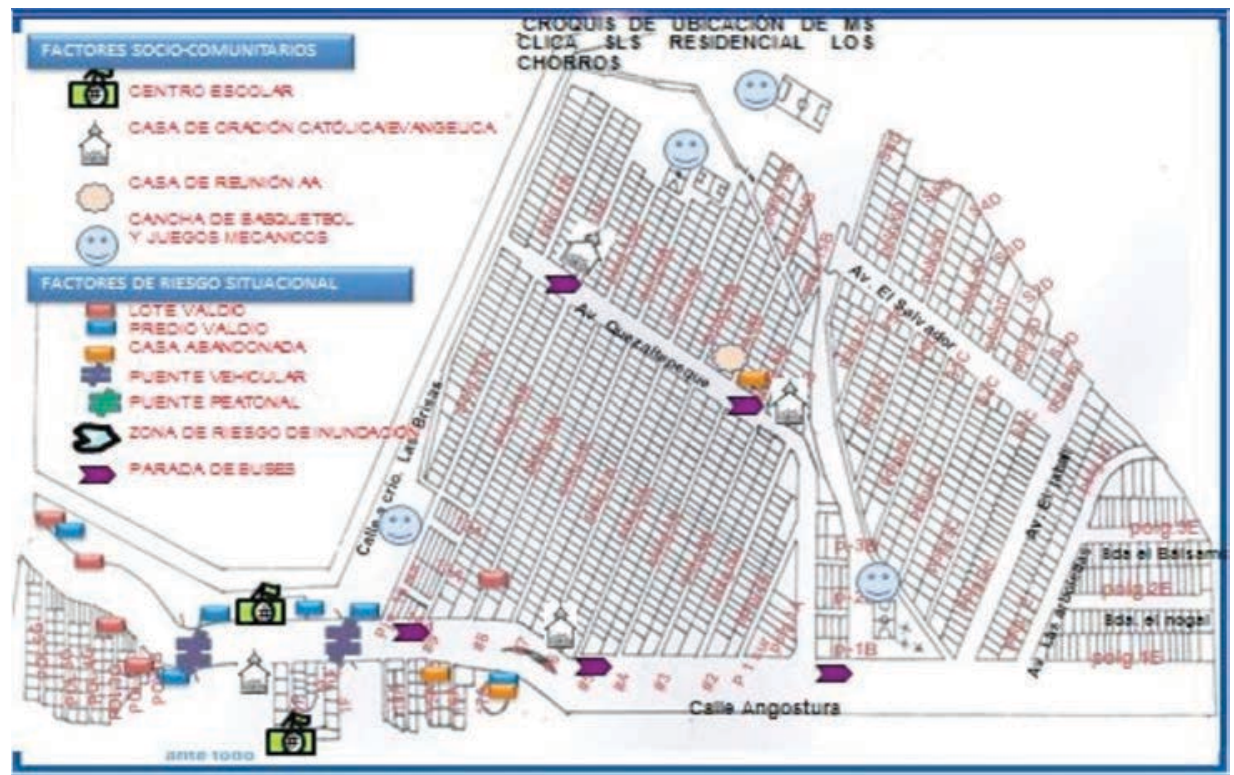

Fuentes: Departamento de Investigación Policial, DIP.PNC. 


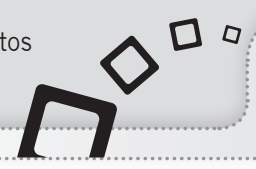

\section{Anexo 6. Casas con grafitis en las residencial Los Chorros}

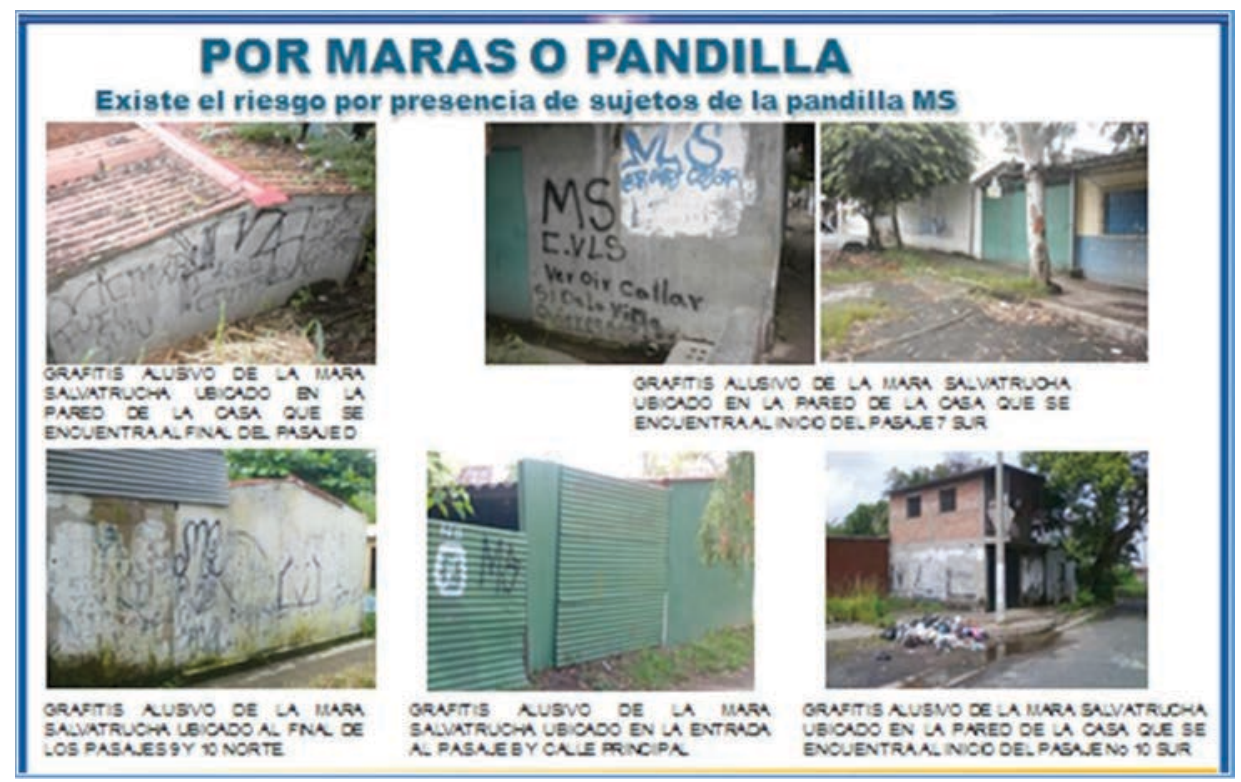

Fuente: Departamento de Investigaciones de la PNC. 
